\title{
Desulphurisation of Biogas: A Systematic Qualitative and Economic-Based Quantitative Review of Alternative Strategies
}

\author{
Oseweuba Valentine Okoro*(D) and Zhifa Sun * \\ Department of Physics, University of Otago, P.O. Box 56, Dunedin 9054, New Zealand \\ * Correspondence: oseweuba.okoro@otago.ac.nz (O.V.O.); zhifa.sun@otago.ac.nz (Z.S.); \\ Tel.: +64-3-479-7812 (Z.S.)
}

Received: 27 June 2019; Accepted: 28 August 2019; Published: 2 September 2019

check for updates

\begin{abstract}
The desulphurisation of biogas for hydrogen sulphide $\left(\mathrm{H}_{2} \mathrm{~S}\right)$ removal constitutes a significant challenge in the area of biogas research. This is because the retention of $\mathrm{H}_{2} \mathrm{~S}$ in biogas presents negative consequences on human health and equipment durability. The negative impacts are reflective of the potentially fatal and corrosive consequences reported when biogas containing $\mathrm{H}_{2} \mathrm{~S}$ is inhaled and employed as a boiler biofuel, respectively. Recognising the importance of producing $\mathrm{H}_{2} \mathrm{~S}$-free biogas, this paper explores the current state of research in the area of desulphurisation of biogas. In the present paper, physical-chemical, biological, in-situ, and post-biogas desulphurisation strategies were extensively reviewed as the basis for providing a qualitative comparison of the strategies. Additionally, a review of the costing data combined with an analysis of the inherent data uncertainties due underlying estimation assumptions have also been undertaken to provide a basis for quantitative comparison of the desulphurisation strategies. It is anticipated that the combination of the qualitative and quantitative comparison approaches employed in assessing the desulphurisation strategies reviewed in the present paper will aid in future decisions involving the selection of the preferred biogas desulphurisation strategy to satisfy specific economic and performance-related targets.
\end{abstract}

Keywords: desulphurisation; biogas; in-situ biogas desulphurisation; anaerobic digestion; post-biogas desulphurisation

\section{Introduction: Hydrogen Sulphide $\left(\mathrm{H}_{2} \mathrm{~S}\right)$ Formation During Anaerobic Digestion and Its Effect} on Biogas Utilisation

Bioenergy recovery from biomass resources may be achieved via the employment of several biomass conversion pathways [1,2]. A review of literatures, however, highlights an upsurge in the application of anaerobic digestion (AD) technologies in recent times [3,4]. This observation may be reflective of the strategic preference of this conversion pathway due to its capability to facilitate a simultaneous management of high moisture organic waste streams while also generating bioenergy in the form of biogas at a reduced cost $[2,5]$. The biogas product is typically composed of carbon dioxide $\left(\mathrm{CO}_{2}\right)$ and biomethane $\left(\mathrm{CH}_{4}\right)$ which are present in volumetric percentages of $30-40 \%$ and $60-70 \%$, respectively [6]. However, although AD technologies for biogas production can be employed in the conversion of a multitude of organic streams to biogas under the action of suitable microbes, the degradation of sulphur containing organics, i.e., proteins, and the reduction of anionic species, i.e., $\mathrm{SO}_{4}{ }^{2-}$, will result in the associated generation of hydrogen sulphide $\left(\mathrm{H}_{2} \mathrm{~S}\right)$ together with the biomethane $[7,8]$. The $\mathrm{H}_{2} \mathrm{~S}$ product may be formed during the anaerobic digestion process via macromolecules undergoing transformations either via an assimilatory pathway or a dissimilatory pathway [9]. These pathways lead to the conversion of sulphur containing compounds 
(SCC) either to soluble sulphides (HS'), which is a precursor to $\mathrm{H}_{2} \mathrm{~S}$ formation, or the consumption of SCC for biosynthesis of amino acids (cysteine and methionine), considered fundamental for intracellular adenosine-5-phosphosulphate activation within the microbes $[9,10]$. In some cases, however, assimilatory reduction of sulphate ions is achieved via so-called 'trophic reactions', thus leading to direct $\mathrm{H}_{2} \mathrm{~S}$ formation [9-11]. According to Mackie et al., [9], bacteria capable of assimilatory sulphate reduction are ubiquitous in digestion substrates, with notable examples belonging to the genera of Veillonella, Megasphaera, and Enterobacteria. On the other hand, the transformation of sulphur containing macromolecules via the dissimilatory pathway always results in bisulfide ( $\left.\mathrm{HS}^{-}\right)$formation rather than the characteristic amino acid production of the assimilatory pathway [9]. Notable examples of microbes capable of sulphur reduction via $\mathrm{HS}^{-}$formation include neutrophilic Desulfotomaculum solfataricum and Desulfotomaculum thermosapovorans [12,13]. Microbes of Desulfotomaculum solfataricum and Desulfotomaculum thermosapovorans are capable of thriving under temperature conditions as high as $60^{\circ} \mathrm{C}$ and $50{ }^{\circ} \mathrm{C}$, respectively $[12,13]$. The formation of $\mathrm{HS}^{-}$via the dissimilatory pathway occurs via the reduction of inorganic and organic sulphur forms (i.e., sulphates) present in the organic feedstock, which occurs as illustrated by the following example equations $[9,14,15]$;

$$
\begin{gathered}
\mathrm{CH}_{3} \mathrm{COO}^{-}+\mathrm{SO}_{4}{ }^{2-}+\mathrm{H}^{+} \rightarrow \mathrm{HS}^{-}+4 \mathrm{H}_{2} \mathrm{O} \\
\mathrm{C}_{2} \mathrm{H}_{5} \mathrm{COO}^{-}+\frac{3}{4} \mathrm{SO}_{4}{ }^{2-} \rightarrow \frac{3}{4} \mathrm{HS}^{-}+\mathrm{CH}_{3} \mathrm{COO}^{-}+\mathrm{HCO}_{3}{ }^{-}+\frac{1}{4} \mathrm{H}^{+} \\
\mathrm{C}_{2} \mathrm{H}_{5} \mathrm{COO}^{-}+\frac{7}{4} \mathrm{SO}_{4}{ }^{2-}+\frac{1}{4} \mathrm{H}^{+} \rightarrow \frac{7}{4} \mathrm{HS}^{-}+3 \mathrm{HCO}_{3}{ }^{-}+\frac{1}{2} \mathrm{H}^{+}+\frac{1}{4} \mathrm{OH}^{-} \\
\mathrm{C}_{3} \mathrm{H}_{7} \mathrm{COO}^{-}+\frac{1}{2} \mathrm{SO}_{4}{ }^{2-} \rightarrow \frac{1}{2} \mathrm{HS}^{-}+2 \mathrm{C}_{2} \mathrm{H}_{5} \mathrm{COO}^{-}+\frac{1}{2} \mathrm{H}^{+} \\
\mathrm{C}_{3} \mathrm{H}_{7} \mathrm{COO}^{-}+\frac{5}{2} \mathrm{SO}_{4}{ }^{2-}+\frac{1}{2} \mathrm{H}_{2} \mathrm{O} \rightarrow \frac{5}{2} \mathrm{HS}^{-}+4 \mathrm{HCO}_{3}^{-}+\frac{3}{4} \mathrm{H}^{+}+\frac{3}{4} \mathrm{OH}^{-}
\end{gathered}
$$

Equations (1)-(5) illustrate the formation of soluble sulphides $\left(\mathrm{HS}^{-}\right)$via reactions involving intermediate products of the anaerobic digestion (AD) of acetates (Equation (1)), propionates (Equations (2) and (3)), and butyrates (Equations (4) and (5)). This shows that sulphate reducers will outcompete with methanogens because they have better affinities for acetate and $\mathrm{H}_{2}$ [16]. Examples of microbes capable of dissimilatory sulphur reductions are organotrophic mesophilic isolated strains of Deltaproteobacteria with some Archaea (Archaeoglobus fulgidus) [17]. It is important to state that dissimilatory sulphate reductions are enzymologically distinct from the assimilatory sulphate reductions. This is because dissimilatory sulphur reductions can only occur under the action of bacteria capable of consuming specific compounds of sulphates, sulphites, or thiosulphates, as opposed to assimulatory sulphur reductions, which are applicable to all sulphur-containing macromolecules [18].

Equations (1)-(5) highlights the formation of soluble sulphides $\left(\mathrm{HS}^{-}\right)$within the digester, which may be converted to dissolved $\mathrm{H}_{2} \mathrm{~S}$ as follows;

$$
\mathrm{H}_{2} \mathrm{~S} \leftrightarrow \mathrm{H}^{+}+\mathrm{HS}^{-}
$$

where the concentrations of the species of $\mathrm{HS}^{-}$and $\mathrm{H}_{2} \mathrm{~S}$ in the aqueous phase are determined using the Henderson-Hasselbach, relationship as follows [19];

$$
\log _{10} \frac{\left[\mathrm{HS}^{-}\right]}{\left[\mathrm{H}_{2} \mathrm{~S}\right]}=\mathrm{pH}+\log _{10} K_{a}
$$

where $\left[\mathrm{HS}^{-}\right]$denotes the concentration of bisulphide ions present in the substrate in molar $(\mathrm{M})$, and $\left[\mathrm{H}_{2} \mathrm{~S}\right]$ denotes the concentration of dissolved $\mathrm{H}_{2} \mathrm{~S}$, present in the substrate, in molar $(\mathrm{M}), p H$ is the $\mathrm{pH}$ level of the substrate, $K_{a}$ denotes the first ionisation constant of $\mathrm{H}_{2} \mathrm{~S}$, specified to be $9.1 \times 10^{-8}$ [20]. 
Using Equations (6) and (7) above, it can be shown that the concentrations of $\mathrm{H}_{2} \mathrm{~S}$ and $\mathrm{HS}^{-}$within the digester are continually in competition, as the $\mathrm{pH}$ within the digester changes from 1 to 14 , as highlighted in Figure 1.

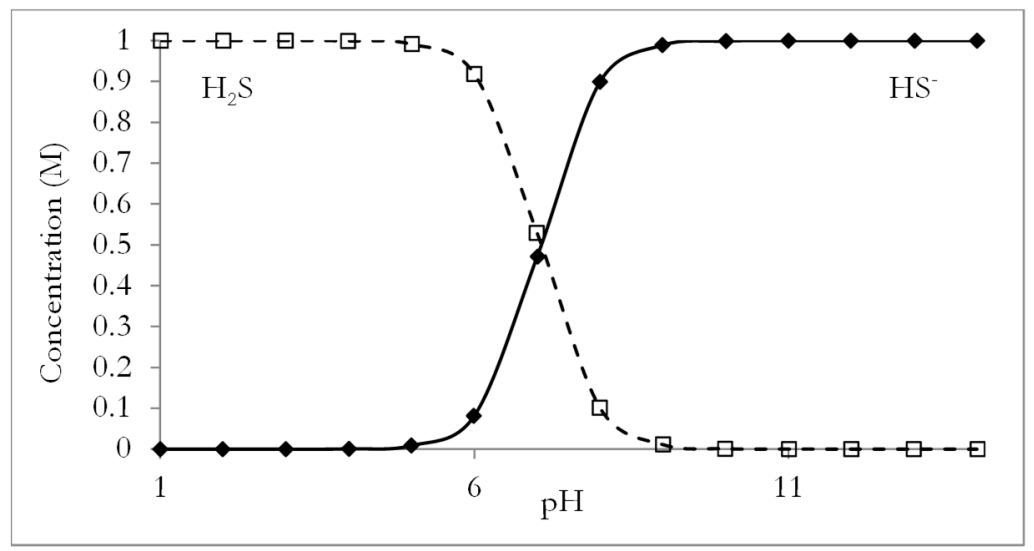

Figure 1. Illustrating the variation of concentrations of dissolved hydrogen sulphide $\left(\mathrm{H}_{2} \mathrm{~S}\right)$ and bisulfide $\left(\mathrm{HS}^{-}\right)$in an aqueous solution with $\mathrm{pH}$ of the digester.

The importance of the $\mathrm{H}_{2} \mathrm{~S}$ content of biogas is reinforced by the possibility of generating biogas with $\mathrm{H}_{2} \mathrm{~S}$ concentrations of about $18,000 \mathrm{mg} / \mathrm{m}^{3}(\approx 1.32 \% \mathrm{v} / \mathrm{v})[7,8]$. High $\mathrm{H}_{2} \mathrm{~S}$ concentration in biogas is undesirable, since there is a risk of $\mathrm{H}_{2} \mathrm{~S}$ release (during biogas collection and transfer) which may lead to pulmonary oedema in humans at concentrations higher than $\sim 400 \mathrm{mg} / \mathrm{m}^{3}(\approx 0.029 \% \mathrm{v} / \mathrm{v})$ [21]. Furthermore, the utilisation of biogas containing $\mathrm{H}_{2} \mathrm{~S}$ as a biofuel for combined heat and power generation also has the potential of leading to the corrosion of engines and the rapid degradation of engine lube oil [22]. The combustion of biogas containing $\mathrm{H}_{2} \mathrm{~S}$ also leads to the formation of sulphur dioxide $\left(\mathrm{SO}_{2}\right)$, via the reaction presented in Equation (1) [22,23].

$$
2 \mathrm{H}_{2} \mathrm{~S}+3 \mathrm{O}_{2} \rightarrow 2 \mathrm{SO}_{2}+2 \mathrm{H}_{2} \mathrm{O}
$$

$\mathrm{SO}_{2}$ is a precursor for acid rain formation that is responsible for several negative impacts on the environment, such as the destruction of agricultural vegetation and pollution of the surrounding aquatic environment [22,23]. It is also possible for the formation of $\mathrm{H}_{2} \mathrm{SO}_{4}$, which is a strongly corrosive acid that may be formed when $\mathrm{H}_{2} \mathrm{~S}$ reacts with water, leading to corrosive effects on equipment [24]. It is therefore necessary to ensure that the $\mathrm{H}_{2} \mathrm{~S}$ content in biogas is minimised, thus limiting the occurrence of the negative effects discussed above. Indeed, the European committee of standards specifies that the preferred biogas product for use as biofuel should have a $\mathrm{H}_{2} \mathrm{~S}$ concentration of $<20 \mathrm{mg} / \mathrm{m}^{3}(\approx 0.0015 \% \mathrm{v} / \mathrm{v})$ [25]. The biogas composition must be ascertained prior to its utilisation, with appropriate strategies employed to limit the $\mathrm{H}_{2} \mathrm{~S}$ content of biogas and facilitate the generation of ' $\mathrm{H}_{2} \mathrm{~S}$-free' biogas.

The present study will therefore provide a qualitative review of major desulphurisation technologies while also incorporating a quantitative dimension to the comparison of these technologies. The importance of this review is reinforced by the absence of publications that provide an exhaustive review of all major technologies integrated with simplified quantitative economic considerations.

\section{Methodology Employed}

In this present study, an initial qualitative review of the alternative desulphurisation technologies was undertaken via a structured approach which incorporates several steps, namely, relevant study identification, screening of existing study contributions, and the analysis of previously reported data as a basis for establishing logical review conclusions. These steps are identified as crucial requirements in achieving a systematic review of any subject matter [26]. The comparison of alternative 
desulphurisation technologies was achieved through a rigorous consideration of relevant journal papers and books available from the institute for scientific information (ISI) web of knowledge database. Numerous searches were conducted using key phrases such as 'desulphurisation of biogas' and 'technologies for $\mathrm{H}_{2} \mathrm{~S}$ removal' to enable an efficient web-search for relevant publications.

After qualitative reviews of the different biogas desulphurisation strategies were concluded, comparative quantitative assessments were undertaken to aid future decisions with respect to the selection of the preferred desulphurisation strategy. Quantitative assessments were undertaken by comparing estimated unit desulphurisation costs. In undertaking a quantitative analysis of the different desulphurisation technologies, difficulties associated with obtaining costing data for the different desulphurisation technologies in a unified manner were appreciated. In other words, it may be difficult to truly represent economic differences for data obtained from different sources. This is a common challenge when comparisons of processes are undertaken based on economic data obtained from the literature, with Ref. [27] employing economic data published in the European Union as an approach to reduce possible interpretational discrepancies. The quantitative review in the present paper therefore sought to utilise data, obtained based on studies undertaken in the member countries of the organisation for economic co-operation and development (OECD). Thus, while a comprehensive unification of the costing data obtained from different countries may be difficult, it is expected that the cost estimates and the conclusions reached may give an overall impression of the most economically favourable desulphurisation technology. In an attempt to further improve the applicability of the costing estimates obtained, the results were assessed via an incorporation of uncertainties for $50 \%$ to $150 \%$ variations in the annual operating cost and the annualised capital costs. The inclusion of uncertainty considerations is discussed further in Section 2.2 below.

Based on literature obtained costing data, the unit desulphurisation cost, $U_{c}$, in US $\$ / \mathrm{m}^{3}$ of biogas was therefore calculated as follows;

$$
U_{c}=\frac{C_{2019}+P_{2019}}{V_{2019}}
$$

where $C_{2019}$ and $P_{2019}$ are the annualised capital cost and the annual operating cost in US $\$$, and $V_{2019}$ is the volume of biogas desulphurised in the year of 2019. In the present study it was assumed that all desulphurisation technologies are capable of operating for $7200 \mathrm{~h}$ per year. The methods employed in estimating the annualised capital cost and the annual operating cost components are discussed in the subsequent subsections.

\subsection{Annual Operating and Annualised Capital Cost per Unit Volume Cost}

Depending on data availability, several methods were employed in estimating the annualised capital cost and annual operating cost. In one approach, the capital cost per unit volume of biogas desulphurised, $c$, in US $\$ / \mathrm{m}^{3}$ and operating cost per unit volume of biogas desulphurised, $p$, in US $\$ / \mathrm{m}^{3}$ were available in the literature and thus utilised as a basis for estimating the annualised capital cost, $C_{i}$, in US $\$$, in the $i$ th year and the annual operating cost, $P_{i}$, in US $\$$, in the $i$ th year as follows:

$$
\begin{aligned}
& c v=C_{i} \\
& p v=P_{i}
\end{aligned}
$$

where $v$ specifies the biogas desulphurisation capacity in $\mathrm{m}^{3}$.

To reflect possible effects of inflation, the annualised capital cost in the present year of $2019\left(C_{2019}\right)$ was estimated from the calculated annualised capital cost for the reference year of $i\left(C_{i}\right)$, using the chemical engineering plant cost (CEPCI) index as follows [28];

$$
C_{2019}=C_{i}\left[\frac{C E P C I_{2019}}{C E P C I_{i}}\right]
$$


where $C E P C I_{2019}$ was specified as 603.1 [29], which is the mean value reported for the year 2018, as the authors had no access to the CEPCI value for the year 2019 at the time of drafting this manuscript. The value of the CEPCI $I_{\mathrm{i}}$ employed will be determined by the reference year, $i$, from whence the data was obtained.

In another approach, the purchase costs for equipment employed in the desulphurisation technologies were available in the literature. The equipment purchase costs were employed in calculating necessary costing inputs for the estimation of the inside battery costs (ISBL) and the investment cost as follows [30,31];

$$
\begin{gathered}
I S B L_{i, \text { vref }}=f_{L} \sum_{a}^{n} \operatorname{Cost}_{a, \text { vref }} \\
T_{i, \text { vref }}=2.05 \times I S B L_{i, \text { vref }}
\end{gathered}
$$

where the Cost $t_{a, v r e f}$ denotes the purchase cost of the ath equipment in the desulphurisation system of reference capacity, vref in $\mathrm{m}^{3}, I S B L_{i, \text { vref }}$ is the inside battery cost in US $\$$ for the year, $i$, and for the desulphurisation system of reference capacity, vref in $\mathrm{m}^{3}, f_{L}$ is the Lang factor specified as $2.47 ; 2.05$ is the conversion factor of $I S B L_{i, \text { vref }}$ to the total investment cost, $T_{i, \text { vref }}$ in US $\$$ estimated for the year, $i$, for the desulphurisation system of reference capacity, vref in $\mathrm{m}^{3}[30,31]$;

The annualised capital cost in US $\$$ for year $i$, for biogas desulphurisation system, with reference capacity, vref in $\mathrm{m}^{3}$, and denoted by $C_{i \text {,rref }}$ was subsequently estimated as follows [28];

$$
C_{i, v r e f}=T_{i, v r e f}\left[\frac{(1+j)^{n} \times i}{(1+j)^{n}-1}\right]
$$

where $n$ is the plant lifespan assumed to be 10 years and $j$ is the discount rate assumed to be $10 \%$.

The calculation of the annualised capital cost estimate for a different capacity, $v$ in $\mathrm{m}^{3}$, from the annualised capital cost for the reference gas capacity, vref in $\mathrm{m}^{3}$, was achieved as follows [32];

$$
C_{i}=C_{i, \text { vref }}\left(\frac{v}{\text { vref }}\right)^{k}
$$

where $C_{i}$ is the annualised capital cost for a desulphurisation plant with a capacity of $v$, in $\mathrm{m}^{3}, C_{i, v r e f}$ is the annualised capital cost for a plant with a reference capacity $v r e f, \mathrm{in}^{3}$, and $k$ is the scaling factor specified as 0.7 [32]. All estimates in Equation (16) are for the year $i$.

To account for inflation considerations, annualised capital cost in the present year of $2019\left(C_{2019}\right)$ was estimated using the CEPCI, as described in Equation (12). During the course of the review of the economic performances of the alternative desulphurisation technologies, a basis of $1000 \mathrm{~m}^{3} / \mathrm{h}$ of $\mathrm{H}_{2} \mathrm{~S}$ containing biogas (also called sour biogas) has been assumed to be available. It has also been assumed that operating costing estimates obtained from the literature did not change significantly over the years. In addition to the aforementioned assumptions, it is important to recognise that the economic assessments of competing desulphurisation technologies are strongly influenced by peculiar properties (i.e., temperature, $\mathrm{H}_{2} \mathrm{~S}$ concentration) of the biogas product [33]. This clearly implies that any conclusions based on the economic assessments, are largely indicative, and capable of serving only as a guide to support decisions regarding the applicability of the desulphurisation technologies in practice.

\subsection{A Consideration of the Inherent Uncertainties in the Costing Data}

Due to the limitations of the economic approach discussed in Section 2.1 above, the applicability of the economic assessment results was tested by assessing uncertainties in the unit desulphurisation $\operatorname{cost} U_{c}$. The uncertainties in the unit desulphurisation cost $U_{c}$ were estimated for the different 
desulphurisation technologies for $50 \%$ to $150 \%$ variations in the annual operating cost and the annualised capital costs. Investigations into uncertainties in the $U_{c}$ estimates for the different desulphurisation technologies were achieved via Monte Carlo simulations that employ randomised sequences of estimates to numerically determine its probability density according to the probability density function, defined as follows [28];

$$
f(x)=\frac{1}{\sqrt{2 \pi} \cdot \sigma} \cdot e^{-\frac{1}{2}\left(\frac{x-\mu}{\sigma}\right)^{2}}
$$

where $x$ represents the values of the $U_{c}$ for different values of annual operating cost, annualised capital cost, interest rate, and the project lifetime, $\mu$ represents the mean value of $U_{c}$, and $\sigma$ represents the standard deviation of $U_{c}$.

This approach has been employed in a previous study [28], where the area under the curve of $f(x)$ for the interval $(a, b)$ specifies the probability, $\beta$, of $U_{c}$ existing within that interval $(a, b)$ and is calculated using the probability density function as follows [28];

$$
\beta(a<x<b)=\int_{a}^{b} f(x) d x
$$

In the present study, 1000 different combinations of the annual operating cost and annualised capital cost estimates have been generated using Minitab ®V17 (Minitab, LEAD Technologies, Inc., Charlotte, NC, USA) to reduce computational time. To aid an easy comparison of the results obtained for the different desulphurisation technologies investigated, a box and whisker plot was utilized, rather than a probability distribution plot, for each individual technology.

\section{Qualitative Review of the Strategies for Biogas Desulphurisation}

In this section, major desulphurisation technologies have been qualitatively reviewed. The technologies have been categorised into major classifications of physical-chemical desulphurisation strategies and biotechnological desulphurisation strategies. These classifications are discussed in subsequent subsections.

\subsection{Physical-Chemical Desulphurisation Methods}

Physical-chemical desulphurisation methods typically involve technologies that employ physical or chemical phenomena in preventing or limiting the formation of $\mathrm{H}_{2} \mathrm{~S}$ during anaerobic digestion processes.

\subsubsection{In-Situ Chemical Precipitation}

The in-situ chemical precipitation desulphurisation strategy refers to approaches that are localised within the digester and that can limit the conversion of dissolved sulphides in the digester to $\mathrm{H}_{2} \mathrm{~S}$ via their conversion to insolubles within the digester $[34,35]$. The formation of insolubles is achieved via the dosing of the digester using chemicals that are capable of converting dissolved sulphides to either insoluble metallic sulphide compounds or insoluble elemental sulphur [35,36]. Generally speaking, divalent $\left(\mathrm{Fe}^{2+}\right)$ and trivalent $\left(\mathrm{Fe}^{3+}\right)$ iron salts are the most commonly employed chemicals to enable the precipitation of sulphides [37]. These salts include chlorides of $\mathrm{Fe}^{3+}$ and $\mathrm{Fe}^{2+}$, iron (III) oxide-hydroxide $(\mathrm{FeOOH})$, and iron $(\mathrm{III})$ hydroxide $\left(\mathrm{Fe}(\mathrm{OH})_{3}\right)[34,38]$. The precipitation of sulphides occurs via reactions as follows $[34,38]$;

$$
\begin{gathered}
\mathrm{FeCl}_{2}+\mathrm{HS}^{-}+\mathrm{H}^{+} \rightarrow \mathrm{FeS}+2 \mathrm{HCl} \\
\mathrm{FeCl}_{3}+2 \mathrm{HS}^{-}+\mathrm{H}^{+} \rightarrow \mathrm{FeS}+3 \mathrm{HCl}+\mathrm{S}
\end{gathered}
$$




$$
\begin{aligned}
& 2 \mathrm{FeOOH}+3 \mathrm{HS}^{-}+3 \mathrm{H}^{+} \rightarrow 2 \mathrm{FeS}+\mathrm{S}+4 \mathrm{H}_{2} \mathrm{O} \\
& 2 \mathrm{Fe}(\mathrm{OH})_{3}+3 \mathrm{HS}^{-}+3 \mathrm{H}^{+} \rightarrow 2 \mathrm{FeS}+\mathrm{S}+6 \mathrm{H}_{2} \mathrm{O}
\end{aligned}
$$

According to SevernWye [39], the chemical dosing desulphurisation approach for sulphite precipitation using salts of $\mathrm{Fe}^{2+}$ and $\mathrm{Fe}^{3+}$ constitutes an easy approach that can be readily retrofitted to existing plants, such that handling and monitoring concerns are minimal. However, while the method is clearly straightforward, the employment of chemicals to aid sulphide precipitation suggests a constant dosing requirement if the desulphurisation process is to be sustained. The need therefore arises for the introduction of auxiliary equipment, such as pumps, to maintain a chemical supply, thus increasing the number of unit operations [40]. Furthermore, although it is possible to approximate the mass of $\mathrm{Fe}$ ions (either $\mathrm{Fe}^{2+}$ or $\mathrm{Fe}^{3+}$ ) employed in dosing the substrate for sulphide precipitation using empirical relations, such as Equation (23) [41], there still exist significant difficulties in controlling the actual degree of desulphurisation that can be achieved [39].

$$
F e=\beta \frac{M_{F e}}{M_{S}}\left[\left(\frac{\mathrm{H}_{2} \mathrm{~S}}{f_{\mathrm{H}_{2} \mathrm{~S}}} V_{\text {substrate }}\right)+\left(\frac{\Delta \mathrm{H}_{2} \mathrm{~S}}{1000} \rho_{\mathrm{H}_{2} \mathrm{~S}} V_{\text {biogas }}\right)\right]
$$

where $\mathrm{Fe}$ represents the iron ions supplied in $\mathrm{g} / \mathrm{d}, \mathrm{H}_{2} \mathrm{~S}$ denotes the total mass of dissolved $\mathrm{H}_{2} \mathrm{~S}$ in $\mathrm{g} / \mathrm{m}^{3}$, $f_{\mathrm{H} 2 \mathrm{~S}}$ denotes the mass fraction of total dissolved sulphur present as dissolved $\mathrm{H}_{2} \mathrm{~S}, \Delta \mathrm{H}_{2} \mathrm{~S}$ denotes the mass of $\mathrm{H}_{2} \mathrm{~S}$ that is removed from the biogas in ppmv, $V_{\text {Substrate }}$ represents feed rate of the substrate in $\mathrm{m}^{3} / \mathrm{d}, V_{\text {biogas }}$ denotes the biogas flowrate in $\mathrm{m}^{3} / \mathrm{d}, \rho_{\mathrm{H} 2 \mathrm{~S}}$ denotes the density of $\mathrm{H}_{2} \mathrm{~S}$ in $\mathrm{g} / \mathrm{L}$ under prevailing conditions of temperature and pressure, $M_{F e}$ represents the molecular mass of iron in gmole, $M_{S}$ denotes the molecular mass of sulphur in gmole, and $\beta$ denotes the correction factor introduced to account for over dosing, since the iron ions may react with other organics, such as phosphates, that may be present in the system. The $\beta$ value may range from 1.7 to 5 [41].

The challenge of the need for sustained chemical dosing may be responsible for the prevalence of technological applications on small scale operations [42], with a few studies (i.e., the study of [43]) exploring the technology on a large scale. In addition to the need for a sustained supply of chemicals for sulphide oxidation, recent studies have also shown that dosing of substrates with salts of $\mathrm{Fe}^{2+}$ and $\mathrm{Fe}^{3+}$ may impede the bioavailability of useful phosphates, thus hindering the ability of micro-organisms to metabolise organic substrates for biomethane formation [44,45]. Indeed, in the studies undertaken by Al-Imarah et al. [45] and Ofverstrom et al. [46], volumetric biomethane (and net biogas) reductions of $20 \%$ and $30 \%$, respectively, were observed when substrate was dosed with salts of $\mathrm{Fe}^{2+}$ and $\mathrm{Fe}^{3+}$ compared to the volume of biogas produced in the absence of substrate chemical dosing. Another possible limitation to the utilisation iron salts for sulphide removal is the risk of system clogging due to the accumulation of precipitated metallic sulphides along the piping line [47].

\subsubsection{Absorption Technologies}

This approach involves the direct interaction of biogas with water or the direct interaction of biogas with suitable organic solvents via conventional gas-liquid contactors (packed bed or spray towers) [48]. Such interactions will enable the physical absorption of $\mathrm{H}_{2} \mathrm{~S}$ by water or the chemical conversion of $\mathrm{H}_{2} \mathrm{~S}$ to elemental sulphur or metal sulphide, depending on the organic solvent utilised [48]. The physical absorption of $\mathrm{H}_{2} \mathrm{~S}$ using water is also called water scrubbing and is based on the physical effect of dissolving gases in liquids, more so, $\mathrm{H}_{2} \mathrm{~S}$ is significantly more soluble than biomethane under similar conditions [49]. For instance, the solubility of biomethane and the solubility of $\mathrm{H}_{2} \mathrm{~S}$ at a temperature of $20^{\circ} \mathrm{C}$ are reported to be $0.023 \mathrm{~g} / \mathrm{kg}$ of water and $3.78 \mathrm{~g} / \mathrm{kg}$ of water, respectively [50]. While the physical absorption desulphurisation approach is a cheap technique that can enable the generation of energy dense biogas characterised with a biomethane content greater than $97 \% \mathrm{v} / \mathrm{v}$, some issues associated with unwanted microbial growth on the surface of packing material have been reported [51]. These issues of microbial growth may lead to reduced flexibility toward compositional variability of the biogas 
input and significant water consumption, moreso if the absorption efficiency is to be sustained [51]. As stated briefly above, in addition to the use of water, physical absorption may be achieved using other organic solvents, such as the dimethyl ether of polyethylene glycol (commercially known as Selexol), which has a general formula of $\mathrm{CH}_{3} \mathrm{O}\left(\mathrm{C}_{2} \mathrm{H}_{4} \mathrm{O}\right) \mathrm{nCH}_{3}$ ( $\mathrm{n}=2$ to 9) $[48,52]$. This dimethyl ether of polyethylene glycol has been reported to show an enhanced affinity for $\mathrm{H}_{2} \mathrm{~S}$ (five times compared to water) $[48,52]$. The higher solubility of $\mathrm{H}_{2} \mathrm{~S}$ in the organic solvent of Selexol suggests that a reduced mass of Selexol will be required compared to the mass of water required for an equivalent absorption efficiency. The utilisation of solvents to enable the absorption of $\mathrm{H}_{2} \mathrm{~S}$ via its solubility may be loosely referred to as physical absorption. In other cases, chemicals are employed to enhance the removal of $\mathrm{H}_{2} \mathrm{~S}$ from biogas via the so-called chemical absorption. In other words, the functionality of such chemical absorbers is not solely dependent on the physically solubility of $\mathrm{H}_{2} \mathrm{~S}$ in the solvent, but also on the oxidation of $\mathrm{S}^{-2}$ to $\mathrm{S}$ or conversion to sulphide salts via chemical reactions. The use of several chemical reagents as $\mathrm{H}_{2} \mathrm{~S}$ absorbers have been reported in the literatures, such as $\mathrm{NaOH}, \mathrm{FeCl}_{2}$, $\mathrm{Fe}^{3+} / \mathrm{MgO}, \mathrm{Fe}(\mathrm{OH})_{3}, \mathrm{Fe}^{3+} / \mathrm{CuSO}_{4}$, and $\mathrm{Fe}^{3+} /$ ethylene diamine tetra-acetic acid (EDTA) [48]. It should be immediately clear that after the initial dissolution of $\mathrm{H}_{2} \mathrm{~S}$ gas in the chemical reaction solution, oxidation of $\mathrm{H}_{2} \mathrm{~S}$ in the solution of chemical reagents of $\mathrm{FeCl}_{2}$ and $\mathrm{Fe}(\mathrm{OH})_{3}$ for appropriate iron salt precipitate formation occurs according to the reaction equations previously described in Section 3.1.1 above. According to [53], the utilisation of $\mathrm{NaOH}$ in chemical absorption constitutes one of the oldest approaches employed in $\mathrm{H}_{2} \mathrm{~S}$ removal from biogas, with the associated formation of either $\mathrm{Na}_{2} \mathrm{~S}$ or NaHS in accordance with the following reaction equations;

$$
\begin{aligned}
& \mathrm{H}_{2} \mathrm{~S}+2 \mathrm{NaOH} \rightarrow \mathrm{Na}_{2} \mathrm{~S}+\mathrm{H}_{2} \mathrm{O} \\
& \mathrm{H}_{2} \mathrm{~S}+\mathrm{NaOH} \rightarrow \mathrm{NaHS}+\mathrm{H}_{2} \mathrm{O}
\end{aligned}
$$

The utilisation of the chemical absorber of $\mathrm{Fe}^{3+} / \mathrm{EDTA}\left(\mathrm{Fe}^{3+}\right.$ to EDTA ratio ranging from 0.909 to 0.5) enables $\mathrm{H}_{2} \mathrm{~S}$ removal via its oxidation to elemental sulphur [54]. Since the formation of elemental sulphur is encouraged, the utilisation of chelates to enable $\mathrm{H}_{2} \mathrm{~S}$ removal is considered a more environmentally favourable approach compared to the utilisation of simple chemical absorbers that produce metallic sulphides [55]. This process of $\mathrm{H}_{2} \mathrm{~S}$ removal is also known as the oxidative absorption process [56]. EDTA is a chelant that performs the function of preventing the formation of insoluble iron compounds without impeding the ability of iron to undergo reduction during the desulphurisation process and oxidation during the regeneration process as follows [54];

$$
\mathrm{H}_{2} \mathrm{~S}+2 \mathrm{Fe}^{3+} / \mathrm{EDTA}^{\mathrm{n}-} \rightarrow \mathrm{S}+2 \mathrm{H}^{+}+2 \mathrm{Fe}^{2+} / \mathrm{EDTA}^{\mathrm{n}-}
$$

with the regeneration of the chelant occurring as follows;

$$
\mathrm{O}_{2}+4 \mathrm{Fe}^{2+} / \mathrm{EDTA}^{\mathrm{n}-}+2 \mathrm{H}_{2} \mathrm{O} \rightarrow 4 \mathrm{Fe}^{3+} / \mathrm{EDTA}^{\mathrm{n}-}+4 \mathrm{OH}^{-}
$$

where ' $n$ ' represents the charge of the chelant anion. Oxidative absorption processes using chelates occur at conditions of moderate temperatures of $20-60^{\circ} \mathrm{C}$, atmospheric pressure condition ( $\left.1 \mathrm{~atm}\right)$, and $\mathrm{pH}$ conditions ranging from 4-8 [54]. Most importantly, the capacity to directly regenerate the chelant coupled with an enhanced $\mathrm{H}_{2} \mathrm{~S}$ (chemical) absorption attainable suggests that lower masses of the chelate will be required, compared to the masses, required when chemicals such as $\mathrm{NaOH}$, discussed earlier above, are employed.

In conclusion, $\mathrm{H}_{2} \mathrm{~S}$ removal from biogas via absorption process have been demonstrated to present removal efficiencies of $99 \%$ and $98 \%$ on lab-scale and pilot scale operations, respectively, with a strong argument for its industrial application, since a scaled up absorption process presents a removal efficiency of as high as $97 \%[57,58]$. 


\subsubsection{Adsorption Technologies}

The employment of adsorption technologies for the desulphurisation of biogas are sometimes classified based on the nature of the adsorption forces employed in the desulphurisation process $[59,60]$. Adsorption processes typically occur at conditions of high pressures ranging from 2 to 7 bar and temperatures of about $70{ }^{\circ} \mathrm{C}$ [61]. In general terms, adsorption may be classified as either physisorption or chemisorption processes, with their major differences summarised in Table 1.

Table 1. Major differences between physisorption and chemisorption [62,63].

\begin{tabular}{|c|c|c|}
\hline Differentiating Parameter & Physisorption & Chemisorption \\
\hline Bonding forces & $\begin{array}{l}\text { Van der Waals forces bond the adsorbate } \\
\text { and absorbent with the adsorbate } \\
\text { molecule retaining its gas phase electronic } \\
\text { structure. }\end{array}$ & $\begin{array}{l}\text { Stronger covalent forces are employed } \\
\text { leading to perturbation of the molecular } \\
\text { electronic structure of the adsorbate } \\
\text { molecule }\end{array}$ \\
\hline Adsorption heat & $\begin{array}{l}\text { The enthalpy change during the } \\
\text { adsorption process is usually low and } \\
\text { ranges from } 30 \text { to } 40 \mathrm{~kJ} \cdot \mathrm{mol}^{-1} \text {. }\end{array}$ & $\begin{array}{l}\text { The enthalpy change during the } \\
\text { adsorption process is usually high and } \\
\text { ranges from } 80 \text { to } 800 \mathrm{~kJ} \cdot \mathrm{mol}^{-1} \text {. }\end{array}$ \\
\hline Adsorption layers & Multi-layer adsorption typically occurs. & Monolayer adsorption typically occurs. \\
\hline Temperature requirement & $\begin{array}{l}\text { Varies with the specific adsorbate and } \\
\text { adsorbent employed with low } \\
\text { temperatures considered as favourable. }\end{array}$ & $\begin{array}{l}\text { Higher temperatures considered } \\
\text { favourable. }\end{array}$ \\
\hline Kinetics & It is a reversible process. & $\begin{array}{l}\text { Irreversible as new compounds are } \\
\text { formed at the adsorbent surface. }\end{array}$ \\
\hline
\end{tabular}

In the context of the present review interest, the adsorbate is $\mathrm{H}_{2} \mathrm{~S}$ gas, while the adsorbent may be a solid such as activated carbon, impregnated activated carbon, zeolites, or an iron oxide-based material [64]. Activated carbon is commonly employed as the preferred adsorbent because it is a highly porous material with a high adsorption capacity and is reported as being efficient in the removal of low concentrations of $\mathrm{H}_{2} \mathrm{~S}$ from biogas via the physisorption process [65]. When an adsorbent such as activated carbon is treated or impregnated using a suitable basic solution, such as $\mathrm{NaOH}$ and $\mathrm{KOH}$, the adsorption capacity of the activated carbon is further enhanced, since additional sulphide oxidation processes are occurring via the formation of sulphide salts according to reactions previously described in Section 3.1.1 above. Some studies have employed other chemicals such as $\mathrm{CdSO}_{4}$ for adsorbent 'impregnation' to facilitate $\mathrm{H}_{2} \mathrm{~S}$ removal as follows [66];

$$
\mathrm{CdSO}_{4}+\mathrm{H}_{2} \mathrm{~S} \rightarrow \mathrm{CdS}+\mathrm{H}_{2} \mathrm{SO}_{4}
$$

Another useful adsorbent is zeolite. Zeolites have been employed in previous studies, with adsorption hypothesised to be achieved via chemisorption in the form of reactions occurring between cations present in the zeolite structure and $\mathrm{H}_{2} \mathrm{~S}$ as follows;

$$
\mathrm{H}_{2} \mathrm{~S}+\mathrm{C}^{\mathrm{n}+}(\mathrm{Z}) \rightarrow \mathrm{HZ}+\mathrm{C}^{\mathrm{n}+}(\mathrm{HS})
$$

where $\mathrm{C}^{\mathrm{n}+}$ represents the positively charged cations such as $\mathrm{K}^{+}, \mathrm{Ca}^{2+}, \mathrm{Mg}^{2+}$, and $\mathrm{Na}^{+}$present in the zeolite (Z) structure.

Zeolites have however been reported as presenting a poorer $\mathrm{H}_{2} \mathrm{~S}$ removal performance than alternative adsorbents, such as activated carbon, under moderate temperatures of $30^{\circ} \mathrm{C}$, although its performance increases significantly after steam treatment [67]. Other studies have demonstrated the possibility of enhancing the $\mathrm{H}_{2} \mathrm{~S}$ adsorption properties of Zeolites via the addition of atoms of $\mathrm{Cu}$ and $\mathrm{Zn}$ which can present as d-block metal cations [68]. The improved $\mathrm{H}_{2} \mathrm{~S}$ adsorption performance of zeolites after steam treatment is hypothesised to be due to the additional chemisorption processes as steam treatment encourages the controlled oxidation of metals, leading to the formation of thin metallic 
oxides [69]. These additional chemisorption processes are due to the reaction that occurs between the cationic basic oxides and $\mathrm{H}_{2} \mathrm{~S}$ as follows [69];

$$
\mathrm{H}_{2} \mathrm{~S}+\mathrm{C}^{\mathrm{n}+} \mathrm{O}^{2-} \rightarrow \mathrm{H}_{2} \mathrm{O}+\mathrm{C}^{\mathrm{n}+} \mathrm{S}^{2-}
$$

Enhanced adsorption of $\mathrm{H}_{2} \mathrm{~S}$ after atom substitution with $\mathrm{Cu}^{2+}$ and $\mathrm{Zn}^{2+}$ is largely due to the stronger interaction with $\mathrm{H}_{2} \mathrm{~S}$ due to the improved stability of resulting $\mathrm{CuS}$ and $\mathrm{ZnS}$ [68]. Additional effects of increases in the spaces present within the zeolite cages due to the introduction of a divalent metallic ion may further improve the adsorption capacity of zeolites for polar molecules, but present minimal favourable effects on the adsorption of $\mathrm{H}_{2} \mathrm{~S}$ [68]. The introduction of an appropriate divalent metallic ion may be achieved via ion exchange, pores necking, or prior to an initial adsorption of polar molecules [67]. According to Wang [70], the utilisation of the adsorbent of iron oxide $\left(\mathrm{Fe}_{2} \mathrm{O}_{3}\right)$ is one of the oldest techniques employed in the desulphurisation of dry $\mathrm{H}_{2} \mathrm{~S}$. Iron oxide adsorbents are capable of $\mathrm{H}_{2} \mathrm{~S}$ removal via chemisorption reactions that result in the formation of insoluble iron sulphides as follows [70];

$$
\mathrm{H}_{2} \mathrm{~S}+\frac{1}{3} \mathrm{Fe}_{2} \mathrm{O}_{3} \rightarrow \mathrm{H}_{2} \mathrm{O}+\frac{1}{3} \mathrm{Fe}_{2} \mathrm{~S}_{3}
$$

It is also possible to employ iron (III) hydroxide as an adsorbent for biogas desulphurisation as follows;

$$
3 \mathrm{H}_{2} \mathrm{~S}+2 \mathrm{Fe}(\mathrm{OH})_{3} \rightarrow 6 \mathrm{H}_{2} \mathrm{O}+\mathrm{Fe}_{2} \mathrm{~S}_{3}
$$

In both cases discussed above, the resulting iron sulphides can be oxidised to enable the formation of elemental sulphur and the regeneration of the iron oxide adsorbent as follows [71];

$$
\frac{1}{2} \mathrm{O}_{2}+\frac{1}{3} \mathrm{Fe}_{2} \mathrm{~S}_{3} \rightarrow \mathrm{S}+\frac{1}{3} \mathrm{Fe}_{2} \mathrm{O}_{3}
$$

This oxidation of the resulting iron sulphides would however result in clogging issues in the adsorbent system due to large masses of elemental sulphur produced, causing the need for the intermittent replacement of the adsorption media [70].

According to [72], adsorbents employed in desulphurisation are typically selected based on their adsorption capacity for $\mathrm{H}_{2} \mathrm{~S}$, the kinetics of the adsorption process, the durability as reflected by the mechanical properties, stability of chemical properties, and the multi-functionality of removing other contaminants, such as $\mathrm{NH}_{3}$, from biogas. Additionally, $\mathrm{H}_{2} \mathrm{~S}$ removal from biogas via adsorption has been reported to be quite effective since $\mathrm{H}_{2} \mathrm{~S}$ content of gas can be reduced to low residual concentrations of $<1 \mathrm{ppm}$ [73]. This desulphurisation strategy is currently employed mainly in small scale operations [74], possibly due to the high specific cost. Furthermore, previous work has also highlighted challenges associated with competitive adsorption between $\mathrm{CO}_{2}$ and $\mathrm{H}_{2} \mathrm{~S}$ biogas components, such that the performance of the adsorbent with respect to $\mathrm{H}_{2} \mathrm{~S}$ removal from biogas is diminished by the presence of $\mathrm{CO}_{2}$ in biogas [75]. This is due to the $\mathrm{CO}_{2}$ and $\mathrm{H}_{2} \mathrm{~S}$ biogas components competing for the same adsorption sites [75].

\subsection{Biotechnological Desulphurisation Strategies}

These strategies combine innovative technologies and the sulphide oxidative capacities of specific micro-organisms are mainly in-situ microaeration and biofiltration technologies. These technologies are discussed further in subsequent subsections.

\subsubsection{In-Situ Microaeration Desulphurisation}

As the name implies, it may be intuitively deduced that this technology serves to limit $\mathrm{H}_{2} \mathrm{~S}$ formation via the incorporation of technologies for aeration of the digester headspace $[47,76]$. The potential for unwanted $\mathrm{H}_{2} \mathrm{~S}$ generation during anaerobic digestion processes may be reduced via the oxidation of soluble sulphides in the substrate, with oxidation aided by the presence of sulphur 
oxidising bacteria, and small volumes of oxygen (or air) $[41,77,78]$. The introduction of small doses of air at levels of $<1 \mathrm{~L}$ of $\mathrm{O}_{2}$ per $1 \mathrm{~L}$ of substrate, $1-10 \mathrm{~L}$ per $1 \mathrm{~L}$ of substrate, and $>10 \mathrm{~L}$ per $1 \mathrm{~L}$ of substrate specify the conditions for micro, limited, and full aeration [42]. Some examples of bacteria capable of encouraging the oxidation of $\mathrm{H}_{2} \mathrm{~S}$ in the presence of molecular oxygen include Acidithiobacillus thiooxidans, Thiomonas intermedia, and Thiomonas perometabolis [79]. It was suggested in previous studies that microaeration integrated both chemical and biological reactions for $\mathrm{H}_{2} \mathrm{~S}$ removal $[80,81]$. Microaeration enables the oxidation of $\mathrm{H}_{2} \mathrm{~S}$ present in both the gaseous and aqueous phase to elemental sulphur [82]. According to [83], while elemental sulphur is widely reported as the common sulphide oxidation product, the final product of the microaeration desulphurisation process is largely dependent on the prevailing $\mathrm{H}_{2} \mathrm{~S}$ to oxygen mole ratio. Reactions highlighting the reaction for producing different sulphide oxidation products ( $\mathrm{S}$ or/and $\mathrm{SO}_{4}{ }^{2-}$ ) are as follows [83];

$$
\begin{gathered}
\mathrm{H}_{2} \mathrm{~S}+\frac{1}{2} \mathrm{O}_{2} \rightarrow \mathrm{S}+\mathrm{H}_{2} \mathrm{O} \\
\mathrm{S}+\mathrm{H}_{2} \mathrm{O}+\frac{3}{2} \mathrm{O}_{2} \rightarrow \mathrm{SO}_{4}{ }^{2-}+2 \mathrm{H}^{+} \\
\mathrm{H}_{2} \mathrm{~S}+2 \mathrm{O}_{2} \rightarrow \mathrm{SO}_{4}{ }^{2-}+2 \mathrm{H}^{+}
\end{gathered}
$$

Other studies also highlight the possibility of the oxidation of dissolved sulphide to generate thiosulphates as follows $[84,85]$;

$$
2 \mathrm{HS}^{-}+2 \mathrm{O}_{2} \rightarrow \mathrm{S}_{2} \mathrm{O}_{3}{ }^{2-}+\mathrm{H}_{2} \mathrm{O}
$$

This method is established to be highly efficient, since previous studies have reported the possibility of achieving $\mathrm{H}_{2} \mathrm{~S}$ removal efficiencies of greater than $99 \%$ when operated on a laboratory scale [77]. Long-term large-scale systems have also been reported to present high $\mathrm{H}_{2} \mathrm{~S}$ removal efficiencies of up to $90 \%$, thus clearly highlighting the functionality of this technology under industrial scenarios [86]. While recognising the high desulphurisation efficiencies attainable via the in-situ microaeration approach, it is possible that oxygen introduction may present negative effects on the methanogenic activity of some microbes $[42,87,88]$. Additionally, further oxidation of elemental sulphur may lead to the production of sulphates, which may also inhibit methanogenic activity [89]. It must be stated that microaeration has additional drawbacks associated with the risk of clogging of oxygen supply pipes with elemental sulphur from the partial oxidation of soluble substrates [42]. Additionally, sulfuric acid formation due to $\mathrm{H}_{2} \mathrm{~S}$ oxidation in the presence of water vapour may lead to associated corrosion problems within the digester [90].

In an attempt to overcome the aforementioned challenges associated with in-situ microaeration desulphurisation strategy, recent investigations have explored the possibility of introducing a membrane to separate the biogas from the oxygen supply pipes [91,92]. In the studies presented in Ref. [91] and Ref. [92], it was demonstrated that it was possible to utilise an internal silicone membrane and a polyvinylidene fluoride membrane to prevent the clogging problems while maintaining high sulphide removal efficiency of $96 \%$ and $99.99 \%$, respectively. These challenges may also be limited by the utilisation of a compartment, distinct from the anaerobic digestion vessel, where the microaeration process for $\mathrm{H}_{2} \mathrm{~S}$ oxidation is taking place [93].

\subsubsection{Biofiltration Technologies}

Biofiltration technologies employed in the removal of $\mathrm{H}_{2} \mathrm{~S}$ from biogas include biotrickling filters (BTFs), biofilters (BFs), and bioscrubbers (BS). Biotrickling filters (BTFs) are bioreactors that employ chemically inert packing materials used in immobilising micro-organisms that are capable of sulphide oxidation while also localising wet organic materials as a nutrient source for microorganisms, thus forming a so-called 'filter bed' [94,95]. These microbes grow as biofilms on the packing materials within the filter bed [96]. Given that biofilm formation occurs on the packing material, the packing 
material that best supports microbial growth must be selected. Typically, the best packing materials are materials that have large surface areas relative to their bulk volumes, such as plastic fibres, honeycomb, or open pore polyurethane foam, which are characterised by specific surface areas greater than $600 \mathrm{~m}^{-1}$ [97-99]. Larger surface areas are important since it encourages microbial growth [100]. Other useful properties of packing materials include hydrophobicity and its resistance to degradation from mechanical, chemical, or biological attacks [99]. Additionally, it is important that the moisture content of the filter bed is maintained either by spraying the filter bed with water or by ensuring that a high enough humid gas flow is maintained [101]. BTFs are particularly effective in the removal of $\mathrm{H}_{2} \mathrm{~S}$, since they support diverse bacteria populations [102]. This may be the basis of its ability to remove other contaminants such as $\mathrm{NH}_{3}$, volatile organic compounds (VOCs), and odours with great efficiency $[103,104]$.

The operation of BTFs involves the passing of the contaminated biogas through the wet filter bed over which an aqueous phase is continuously trickled [95]. The passage of the contaminated biogas thorough the wet filter bed enables the dissolution of $\mathrm{H}_{2} \mathrm{~S}$ gas contaminant to the aqueous phase, followed by the diffusion of the dissolved $\mathrm{H}_{2} \mathrm{~S}$ to the biofilm containing the microbes [105]. The dissolved $\mathrm{H}_{2} \mathrm{~S}$ is subjected to microbial action, leading to its oxidation to elemental sulphur or sulphates [105]. This BTF technology may be considered as a mature technology which has been shown to present high $\mathrm{H}_{2} \mathrm{~S}$ removal efficiencies of $\geq 99 \%$ when employed on bench, pilot, and full-scale operations [106-108].

It is important to note that there is a simpler configuration of the BTF called the biofilter [109]. Simple block diagrams to highlight the difference between the BTF and the simpler biofilter are presented in Figure 2. Figure 2 clearly shows that a biofilter [B] differs from the BTF $[A]$ in terms of the movement of nutrient solution, since the nutrient solution is only occasionally replenished compared to the BTFs, where there is a sustained tricking of nutrient laden water for enhanced nutrient circulation within the filter bed [110]. Generally speaking, biofilters constitute an interesting technology that has been explored in previous studies as bench scale [111] and pilot scale operations [112], with large-scale biofilters expected to lead to further improvements in the economic performance [41].

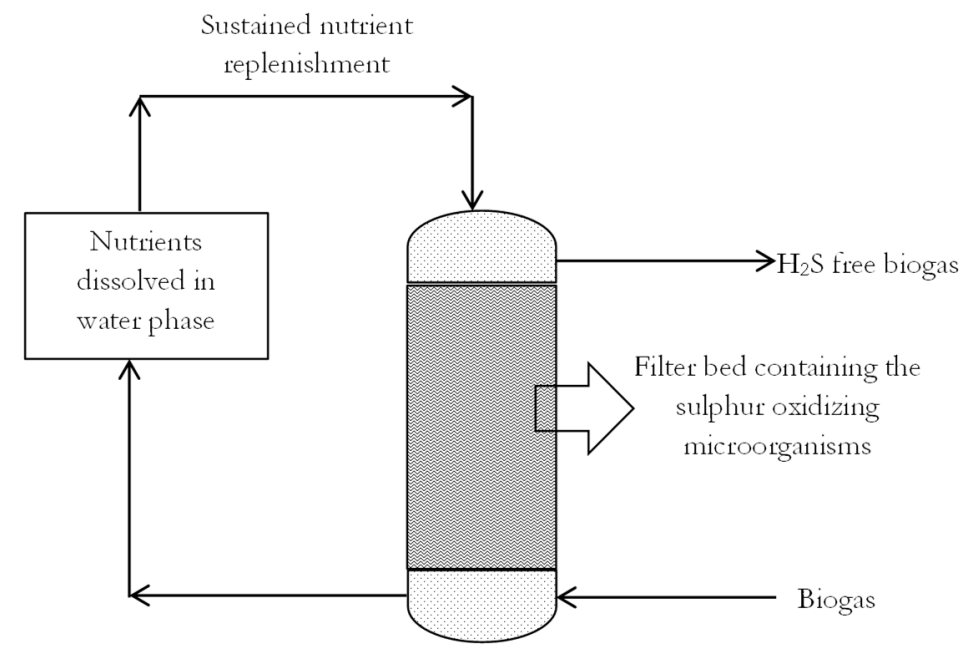

(A)

Figure 2. Cont. 


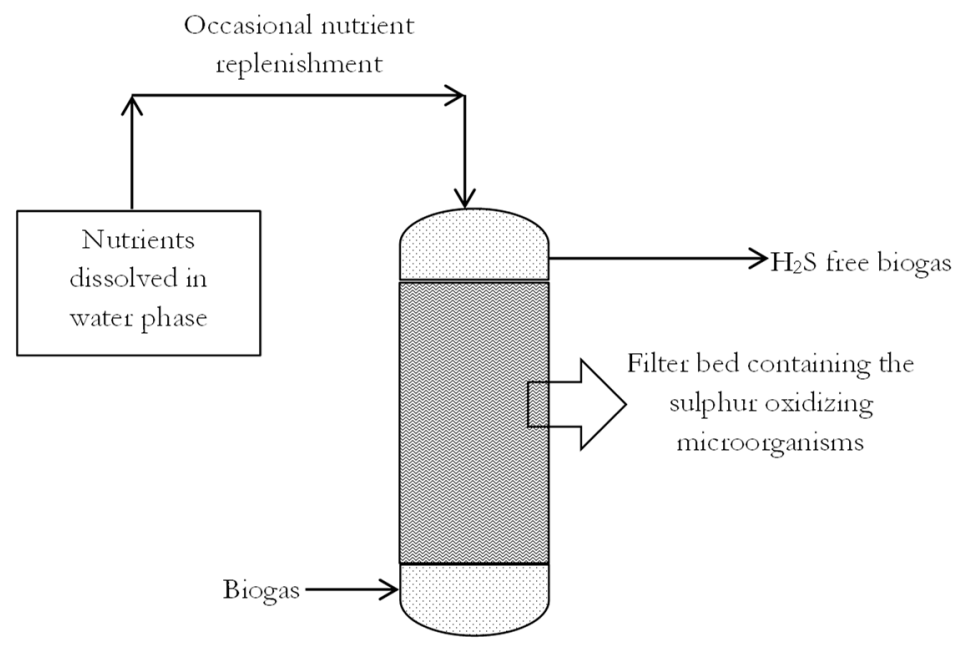

(B)

Figure 2. Simple illustration of a biotrickling filter (A) and a biofilter (B) desulphurisation set for biogas.

Although Figure 2 highlights the configurational simplicity of the biofilter compared to the BTF, biofilters have the major drawback of presenting poor performances, largely due to poor microbial density in the filter beds [109]. Poor microbial density may be a result of reduced access to nutrients by the microbes. Issues of filter bed clogging are, however, common in biofilters and BTFs, suggesting the need for regular cleaning operations [109]. In an attempt to mitigate the aforementioned limitations, biofilter technologies have been developed that exhibit properties similar to biotrickling filters such that water nutrient solution addition, although not continuously available, is supplied intermittently at a higher frequency [113]. There is also some interest in the possibility of utilising sulphur oxidising fungi rather than sulphur oxidising bacteria, since fungi present a higher resistance to acids and low moisture conditions, compared to bacterial biofilms [113]. Bioscrubbers constitute another useful technology that has been shown to be quite effective when employed in pilot scale operations [114]. However, while there are currently a significant number of installations of large-scale biotrickling filters and biofilters globally, the installations of large-scale bioscrubbers constitute the dominant biofilteration technology in small niche markets [113]. The bioscrubbers are able to facilitate the separation of the unwanted $\mathrm{H}_{2} \mathrm{~S}$ present in the biogas via the incorporation of an initial absorption stage for the dissolution of $\mathrm{H}_{2} \mathrm{~S}$ gas, followed by the biological treatment of the resulting $\mathrm{H}_{2} \mathrm{~S}$ containing solution using a reactor containing a suitable microbial population $[115,116]$. The incorporation of these two stages of $\mathrm{H}_{2} \mathrm{~S}$ absorption and biological sulphide oxidation is highlighted in Figure 3.

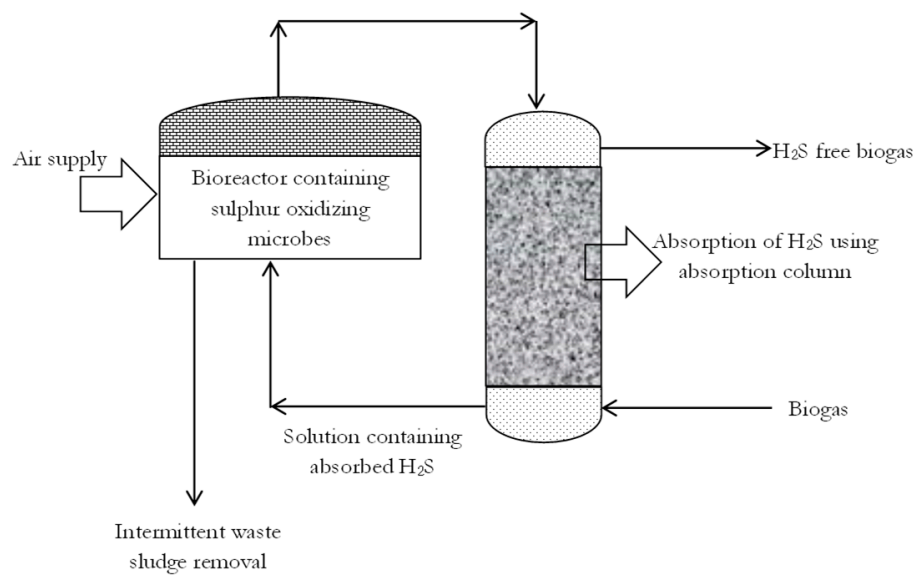

Figure 3. Simple illustration of a bioscrubber highlighting the two steps of initial $\mathrm{H}_{2} \mathrm{~S}$ absorption followed by $\mathrm{H}_{2} \mathrm{~S}$ oxidation. 
The absorption of $\mathrm{H}_{2} \mathrm{~S}$ biogas can be achieved using a suitable solvent (i.e., alkaline solution) and technologies such as a spray empty column, a packed column, or a venturi scrubber [117]. The oxidation of the dissolved sulphide is achieved under the action of relevant sulphide oxidising bacteria that oxidises $\mathrm{H}_{2} \mathrm{~S}$ to either produce $\mathrm{S}$ and/or $\mathrm{SO}_{4}{ }^{2-}$ [117]. General speaking, autotropic sulphur oxidising bacteria are typically photoautotrophs or chemolithotrophs [118], and may be employed in BTF, BF, and BS technologies. Due to the importance of photoautotropes, further discussions regarding these sulphur oxidising bacteria have been presented in a stand-alone section below.

Chemolithotrophs, on the other hand, are able to oxidise the sulphides using oxygen (i.e., aerobic species) as electron acceptors and as presented in microaeration discussions above, or nitrate and nitrite (anaerobic species) as electron acceptors. Discussions with respect to the sulphur oxidising bacteria capable of utilising oxygen as electron acceptors have already been discussed in the in-situ microaeration section above, thus will not be discussed further to avoid repetition.

Sulphide oxidising bacteria that employ nitrates $\left(\mathrm{NO}_{3}{ }^{-}\right)$or nitrites $\left(\mathrm{NO}_{2}{ }^{-}\right)$present in the filter bed and absorption column of the BTFs or BFs and BS, respectively, as electron acceptors belong to a family of colourless sulphide-oxidising bacteria [119]. These microbes are sometimes referred to as autotropic denitrifies [119] and may include morphologically distinct microbes such as Thiobacillus denitrificans [120] and Thiomicrospira denitrificans [121]. The autotropic denitrifies are present in highly diverse ecosystems such as soils, sediments, and hydrothermal vents [122]. The oxidation of dissolved sulphides using nitrates or nitrites as electron acceptors may lead to the formation of elemental sulphur or sulphate and nitrite or nitrogen, depending on the sulphide to nitrates or sulphide to nitrites mole ratio, as illustrated in reaction equations as follows [119,123];

$$
\begin{gathered}
\mathrm{S}^{2-}+1.6 \mathrm{NO}_{3}{ }^{-}+1.6 \mathrm{H}^{+} \rightarrow \mathrm{SO}_{4}{ }^{2-}+0.8 \mathrm{~N}_{2}+0.8 \mathrm{H}_{2} \mathrm{O} \\
\mathrm{S}^{2-}+0.4 \mathrm{NO}_{3}{ }^{-}+2.4 \mathrm{H}^{+} \rightarrow \mathrm{S}+0.2 \mathrm{~N}_{2}+1.2 \mathrm{H}_{2} \mathrm{O} \\
\mathrm{S}^{2-}+\mathrm{NO}_{3}{ }^{-}+2 \mathrm{H}^{+} \rightarrow \mathrm{S}+\mathrm{NO}_{2}{ }^{-}+\mathrm{H}_{2} \mathrm{O} \\
\mathrm{S}^{2-}+4 \mathrm{NO}_{3}{ }^{-} \rightarrow \mathrm{SO}_{4}{ }^{2-}+4 \mathrm{NO}_{2}{ }^{-} \\
\mathrm{HS}^{-}+0.25 \mathrm{NO}_{3}{ }^{-}+1.5 \mathrm{H}^{+} \rightarrow \mathrm{S}+0.25 \mathrm{NH}_{4}{ }^{+}+0.75 \mathrm{H}_{2} \mathrm{O}
\end{gathered}
$$

Further oxidation of elemental sulphur and thiosulphides may also occur in the presence of nitrates to produce sulphates as follows [119];

$$
\begin{gathered}
\mathrm{S}+1.2 \mathrm{NO}_{3}{ }^{-}+0.4 \mathrm{H}_{2} \mathrm{O} \rightarrow \mathrm{SO}_{4}{ }^{2-}+0.6 \mathrm{~N}_{2}+0.8 \mathrm{H}^{+} \\
\mathrm{S}_{2} \mathrm{O}_{3}{ }^{2-}+1.6 \mathrm{NO}_{3}{ }^{-}+0.2 \mathrm{H}_{2} \mathrm{O} \rightarrow 2 \mathrm{SO}_{4}{ }^{2-}+0.8 \mathrm{~N}_{2}+0.4 \mathrm{H}^{+}
\end{gathered}
$$

A notable study that employed autotropic denitrifies in achieving the desulphurisation of biogas is presented in Ref. [97] where BTFs employed nitrate-rich effluent of sequencing batch reactor as both the bacteria source and the nutrient solution. The SBR effluent was also used as the source of microorganisms for the inoculation. Another study presented in Ref. [124] also investigated $\mathrm{H}_{2} \mathrm{~S}$ removal using an anoxic BTF, which was operated using synthetic wastewater as the nitrate source. Another study undertaken in Ref. [125] not only tested the effectiveness of $\mathrm{H}_{2} \mathrm{~S}$ removal in an anoxic biotrickling filter, but also demonstrated that the composition of the microbial community varied for different $\mathrm{H}_{2} \mathrm{~S}$ and $\mathrm{NO}_{3}{ }^{-}$loads. Generally speaking, the employment of biological agents in facilitating the oxidation of sulphides as in the case with in-situ microaeration, BTF and BF can intuitively be considered a more environmentally friendly approach compared to the in-situ chemical dosing strategy discussed above, since all inputs occur in nature with no chemicals employed. It is the view of the authors of the present paper that the major issues associated with employing biological desulphurisation strategies may include the problems of microbe recovery, microbial culturing, and sustained microbial growth via temperature and $\mathrm{pH}$ control. Bioscrubbers have the advantages of having improved 
predictability, reliability, and $\mathrm{pH}$ control, with reduced clogging issues compared to the BTFs and biofilters [116]. Bioscrubbers are, however, characterised by lower abatement efficiencies, a more complicated start up, and waste sludge disposal issues $[116,126]$. The biotechnological approaches discussed so far have been demonstrated to be a sufficient and competitive treatment technology for biogas conditioning when compared to physical-chemical technologies $[94,95,127]$.

\subsubsection{Phototrophic Sulphur Oxidation}

In addition to the chemolithotrophic sulphur oxidising bacteria discussed in Section 3.2.2 above, some previous studies have also demonstrated the possibility of employing phototrophic bacteria to oxidise sulphides to elemental sulphur and sulphates [128,129]. These phototrophic bacteria may be incorporated in the biotechnologies discussed above. The bacteria have the capability to oxidise sulphides to elemental sulphur and sulphate in the presence of light, $\mathrm{CO}_{2}$, and necessary nutrients, with the intensity of the light required dependent on the concentration of sulphides to be oxidised [129]. The relationship between the concentration of the $\mathrm{H}_{2} \mathrm{~S}$ oxidised and light intensity is aptly highlighted using the van Niel curve as presented in Figure 4.

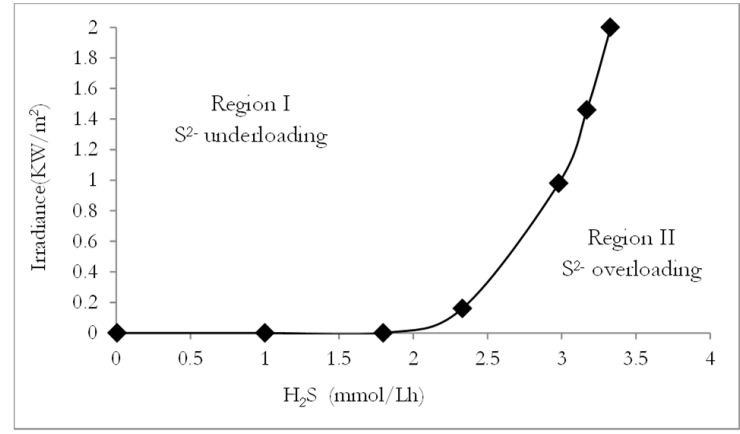

Figure 4. The van Niel curve (adapted from [130]).

Biological desulphurisation via phototropic bacteria activity for $\mathrm{H}_{2} \mathrm{~S}$ removal occurs according to the general equation below [128,129];

$$
2 \mathrm{H}_{2} \mathrm{~S}+\mathrm{CO}_{2} \stackrel{\text { Light }}{\rightarrow} 2 \mathrm{~S}+\mathrm{CH}_{2} \mathrm{O}+\mathrm{H}_{2} \mathrm{O}
$$

Under conditions of constant high light intensity and low sulphide concentration, previous studies suggested that biological desulphurisation may lead to the formation of sulphates as follows [128,129];

$$
\mathrm{H}_{2} \mathrm{~S}+2 \mathrm{CO}_{2}+2 \mathrm{H}_{2} \mathrm{O} \stackrel{\text { Light }}{\rightarrow} \mathrm{SO}_{4}{ }^{2-}+2 \mathrm{CH}_{2} \mathrm{O}+\mathrm{H}_{2} \mathrm{O}
$$

In Equations (45) and (46), $\mathrm{CO}_{2}$ functions as the electron acceptor (oxidising agent). According to Pokorna and Zabranska [131], commonly used phototrophic bacteria employed in desulphurisation include the sulphide-oxidizing green bacteria (genera of Chlorobium and Chromatium) and the sulphide-oxidizing purple bacteria (genera of Allochromatium, Chromatium, Thioalkalicoccus). It is important to reiterate that although this desulphurisation strategy achieves the oxidation of dissolved sulphides in the absence of oxygen, some of these microbes have the capability for biological desulphurisation even when molecular oxygen is present [132]. While recognising that there are a multitude of bacteria capable of oxidising dissolved sulphides, such that each bacterial genera is characterised by unique physiological and biological characteristics, the present review will provide a brief summary of some commonalities and differences between different sulphur oxidising bacteria. A brief summary of some characteristics of sulphur oxidising bacteria has been provided, since an extensive investigation of sulphur oxidising physiology bacteria does not constitute an objective of this review paper. Some notable characteristics of some sulphur oxidising bacteria are therefore summarised in Table 2. 
Table 2. Summary of some notable properties of sulphur oxidising bacteria considered in the present study.

\begin{tabular}{|c|c|c|c|c|}
\hline \multirow{3}{*}{ Some Properties } & \multicolumn{3}{|c|}{ Sulphur Oxidising Bacteria } & \multirow{3}{*}{ References } \\
\hline & \multicolumn{2}{|c|}{ Photoautotrophs } & \multirow{2}{*}{ Chemolithotrophs $^{\text {a }}$} & \\
\hline & Green Sulphur Bacteria & Purple Sulphur Bacteria & & \\
\hline Sulphide oxidation pathway & $\begin{array}{l}\text { Reduces carbon dioxide to } \\
\text { carbohydrates via the } \mathrm{H}_{2} \mathrm{~S} \text { oxidation. }\end{array}$ & $\begin{array}{l}\text { Also capable of undergoing the } \\
\text { phototropic conversion of } \\
\text { carbon dioxide to carbohydrates } \\
\text { via } \mathrm{H}_{2} \mathrm{~S} \text { oxidation. }\end{array}$ & $\begin{array}{c}\text { May oxidize inorganic sulphur } \\
\text { compounds using oxygen, generating } \\
\text { energy (aerobic species such as } \\
\text { Beggiatoa sp) } \\
\text { May also oxidize inorganic sulphur } \\
\text { compounds using nitrogen oxides for } \\
\text { energy generation. Also called } \\
\text { autotropic dentrifiers (i.e., anaerobic } \\
\text { species such as Thiomicrospira } \\
\text { denitrificans. }\end{array}$ & {$[133,134]$} \\
\hline Physiology & $\begin{array}{l}\text { Green bacteria are either non-motile } \\
\text { green or gliding filamentous green } \\
\text { bacteria. } \\
\text { Gas vesicles are present and responsible } \\
\text { for enhanced buoyancy. Chlorosome } \\
\text { complexes are also present and that } \\
\text { serve as 'photosynthetic antennas'. }\end{array}$ & $\begin{array}{l}\text { Most purple bacteria are } \\
\text { flagellated. Typically, gas } \\
\text { vesicles and chlorosomes are } \\
\text { not present. }\end{array}$ & $\begin{array}{l}\text { The chemolithotrophs are typically } \\
\text { considered colourless due to the } \\
\text { absence of photopigments. They may } \\
\text { be motile, filamentous organisms (i.e., } \\
\text { Thiobacillus denitrificans, Beggiatoa) as } \\
\text { the mobility assists in migration to } \\
\text { regions of higher oxygen concentration. } \\
\text { They may also exist as non-motile } \\
\text { organisms } \\
\text { (i.e., Thiomicrospira denitrificans) }\end{array}$ & {$[119,135-139]$} \\
\hline Light response & $\begin{array}{l}\text { Green sulphur bacteria are phototrophs } \\
\text { thus require light. They absorb longer } \\
\text { wavelengths of light than purple } \\
\text { sulphur bacteria since have they have } \\
\text { special adaptations to low light. A } \\
\text { notable example is the green bacteria is } \\
\text { Chlorobium phaeobacteroides which is } \\
\text { reported to be capable of surviving } \\
\text { under a light level of }<0.25 \mu \mathrm{mol} \\
\text { photons } \mathrm{m}^{-2} \mathrm{~s}^{-1} \text {. }\end{array}$ & $\begin{array}{l}\text { Purple sulphur bacteria are } \\
\text { phototrophs thus also require } \\
\text { light. They require shorter } \\
\text { wavelengths of light, } \\
\text { highlighting the need for higher } \\
\text { energy requirement by the } \\
\text { purple bacteria. }\end{array}$ & $\begin{array}{l}\text { Photo-inhibition even in low light } \\
\text { intensities has been reported in } \\
\text { previous studies, with protection from } \\
\text { light considered desirable. }\end{array}$ & {$[133,140,141]$} \\
\hline
\end{tabular}


Table 2. Cont.

\begin{tabular}{|c|c|c|c|c|}
\hline \multirow{3}{*}{ Some Properties } & \multicolumn{3}{|c|}{ Sulphur Oxidising Bacteria } & \multirow{3}{*}{ References } \\
\hline & \multicolumn{2}{|c|}{ Photoautotrophs } & \multirow{2}{*}{ Chemolithotrophs ${ }^{a}$} & \\
\hline & Green Sulphur Bacteria & Purple Sulphur Bacteria & & \\
\hline Oxygen tolerance & Strict obligate anaerobes & $\begin{array}{l}\text { Can survive in the presence of } \\
\text { molecular oxygen (facultative) }\end{array}$ & $\begin{array}{l}\text { Some are dependent on oxygen, thus } \\
\text { they are often localised at the interface } \\
\text { between aerobic and anaerobic zones } \\
\text { where low concentrations of oxygen } \\
\text { and sulphide can coexist (i.e., Beggiatoa } \\
\text { sp and Thioploca sp are aerobic). Other } \\
\text { colorless bacteria may exist as absolute } \\
\text { obligates (i.e., Thiomicrospira } \\
\text { denitrificans) with some species (i.e., } \\
\text { Thiobacillus denitrificans) capable of } \\
\text { consuming low oxygen concentrations. }\end{array}$ & {$[132,139,142,143$} \\
\hline Sulphur availability & $\begin{array}{l}\text { Elemental sulphur is deposited } \\
\text { extracellularly, free of any } \\
\text { encapsulation by proteins. If the } \\
\text { sulphides are depleted in the substrate, } \\
\text { extracellular sulphur globules may be } \\
\text { oxidised completely to sulphate. }\end{array}$ & $\begin{array}{l}\text { Elemental Sulphur is typically } \\
\text { deposited intracellularly as } \\
\text { spherical particles and is } \\
\text { encapsulated by proteins. The } \\
\text { sulphur is further oxidised and } \\
\text { released from the cells as sulphates. } \\
\text { Some species of the purple sulphur } \\
\text { bacteria such as Ectothiorhodospira, } \\
\text { Halorhodospira, Thiorhodospira also } \\
\text { have the capability to deposit } \\
\text { elemental sulphur extracellularly. }\end{array}$ & $\begin{array}{l}\text { There may be an intracellular } \\
\text { accumulation of elemental sulphur. In } \\
\text { some cases, up to } 30 \% \text { of dry cell mass } \\
\text { is sulphur (i.e., Beggiatoa sp). } \\
\text { Large internal vacuoles facilitated the } \\
\text { storage of sulphur within the cell wall }\end{array}$ & {$[131,144-147]$} \\
\hline Sulphide tolerance & $\begin{array}{l}\text { Green sulphur bacteria exhibit a high } \\
\text { tolerance for high concentrations of } \\
\text { sulphides in solution of up to } 5-10 \mathrm{mM} \text {. } \\
\text { This is largely because sulphide } \\
\text { oxidation occurs extracellularly. }\end{array}$ & $\begin{array}{l}\text { High sulphide concentrations (5-10 } \\
\text { mM) are considered toxic to purple } \\
\text { sulphur bacteria largely because } \\
\text { sulphides are oxidised internally. }\end{array}$ & $\begin{array}{l}\text { They do not tolerate very high sulphide } \\
\text { concentrations (i.e., > } 1920 \mathrm{mg} / \mathrm{L} \text { ). }\end{array}$ & {$[146,148-150]$} \\
\hline $\mathrm{CO}_{2}$ fixation pathway & $\begin{array}{c}\mathrm{CO}_{2} \text { fixation is typically achieved via } \\
\text { the reductive tricarboxylic acid (RTCA) } \\
\text { cycle. }\end{array}$ & $\begin{array}{l}\text { The reductive pentose phosphate } \\
\text { (also called Calvin-Benson- } \\
\text { Bassham) cycle is typically } \\
\text { employed in } \mathrm{CO}_{2} \text { fixation. }\end{array}$ & $\begin{array}{l}\mathrm{CO}_{2} \text { fixation is typically achieved via } \\
\text { the reductive ribulosediphosphate } \\
\text { (Calvin) cycle. Some may also be able } \\
\text { to utilise small amounts of exogenous } \\
\text { organic carbon as carbon sources. }\end{array}$ & {$[143,151-153]$} \\
\hline $\begin{array}{l}\text { Bacteriochlorophyll forms of } \\
\text { types a,b,c,d,e and g (letters to } \\
\text { illustrate slight changes in } \\
\text { structure) }\end{array}$ & $\begin{array}{c}\text { Bacteriochlorophylls of c, d, and e are } \\
\text { present }\end{array}$ & $\begin{array}{c}\text { Bacteriochlorophylls of } \mathrm{a} \text { and } \mathrm{b} \text { are } \\
\text { present }\end{array}$ & Photopigments are absent. & [154] \\
\hline
\end{tabular}

${ }^{a}$ The characteristics of aerobic and anaerobic chemolithotrophs tend to overlap 


\section{Quantitative Analysis of the Desulphurisation Alternatives}

A review of literatures provides some costing input that would be valuable in undertaking economic assessments and uncertainty analysis of the alternative desulphurisation technologies. The literature obtained costing input are summarised in Tables 3 and 4. Since the data presented in Tables 3 and 4 are obtained for the year 2015 and 2011, the associated $C E P C I_{\text {ref }}(\mathrm{s})$, discussed earlier in Section 2 above, are specified as 556.8 [29] and 585.7 [155], respectively.

Table 3. Literature obtained equipment purchase cost and operating cost for desulphurisation processes of in-situ chemical dosing and in-situ microaeration desulphurisation approach [32].

\begin{tabular}{|c|c|c|}
\hline Desulphurisation Method $^{\text {a }}$ & Total Operating Cost (US $\$ / y)^{b}$ & ${\text { Equipment Purchase Cost (US } \$)^{b}}^{b}$ \\
\hline In-situ chemical dosing & $12,684.672$ & $0^{\mathrm{d}}$ \\
\hline In-situ microaeration & $3850.704^{c}$ & $25,184.7^{\mathrm{c}}$ \\
\hline
\end{tabular}

Table 4. Literature obtained economic data for desulphurisation processes of chelating iron scrubbing, bioscrubbers, biofilter, biotrickling filters, absorption, and adsorption technologies [41].

\begin{tabular}{|c|c|c|}
\hline Desulphurisation Method & $\begin{array}{l}\text { Capital Cost per Unit Gas } \\
\left.\text { Volume (US } \$ \text { per } \mathrm{m}^{3}\right)^{a}\end{array}$ & $\begin{array}{c}\text { Operating Cost per Unit Gas } \\
\left.\text { Volume (US \$ per } \mathrm{m}^{3}\right)^{a}\end{array}$ \\
\hline Chelating iron ${ }^{b}$ & 0.170 & 0.070 \\
\hline Bioscrubbers & 0.160 & 0.020 \\
\hline Biofilter & 0.090 & 0.030 \\
\hline Biotrickling filters ${ }^{c}$ & 1.480 & 0.010 \\
\hline Absorber ${ }^{\mathrm{d}}$ & 2.334 & 0.018 \\
\hline Adsorption & 1.200 & 0.009 \\
\hline
\end{tabular}

${ }^{a}$ Absorber using chelation iron; ${ }^{b}$ Cost data based on estimates for the year 2011 with currency conversion of $1 €$ to US $\$ 1.12 ;{ }^{\mathrm{c}}$ Mean data for biotrickling filters; ${ }^{\mathrm{d}}$ Mean data for simple absorbers using $\mathrm{NaOH}$ as absorbing solution.

The obtained unit cost $\left(U_{c}\right)$ incurred in desulphurising a unit volume of biogas for the competing desulphurisation technologies discussed earlier above have been determined using methods described in Section 2, with results summarised in Table 5. In the present study, distinctions have not been made between the bacterial forms (denitrifying i.e., Thiobacillus denitrificans, Thiomicrospira denitrificans, or phototrophic) identified as capable of facilitating the biological oxidation of dissolved sulphides [120-122] using biotechnologies of BTFs, BFs, and BS, as discussed earlier above. Also, a generic adsorption desulphurisation process has been specified to simplify the analysis. Given that the purity of the oxygen source for desulphurisation via in-situ micro aeration may vary in terms of the purity of the oxygen supplied (i.e., ranging from $100 \%$ oxygen to air contain oxygen), the mean values of costing data for the in-situ microaeration desulphurisation technology utilising $100 \%$ of $\mathrm{O}_{2}(\mathrm{v} / \mathrm{v})$, $95 \%$ of $\mathrm{O}_{2}(\mathrm{v} / \mathrm{v})$ and air $(\sim 21 \% \mathrm{v} / \mathrm{v})$ [32] as electron donors have been employed as the representative data for simplicity. Employing the literature obtained economic data presented in Tables 3 and 4 the estimated annualised capital cost, annual operating cost, and the unit desulphurisation cost for the competing desulphurisation technologies are presented in Tables 5 and 6. 
Table 5. Estimated ISBL cost, investment cost, annualised capital cost, and total operating cost for desulphurisation processes of in-situ chemical dosing and microaeration.

\begin{tabular}{|c|c|c|c|c|c|c|}
\hline $\begin{array}{l}\text { Desulphurisat } \\
\text { Method }\end{array}$ & $\begin{array}{c}\text { Annual } \\
\text { iopperating } \\
\text { Cost (US \$) }\end{array}$ & $\begin{array}{c}\text { ISBL } \\
\text { Cost-Reference } \\
\text { Capacity } \\
\text { (US \$) }^{b}\end{array}$ & $\begin{array}{l}\text { Investment Cost, } \\
\text { for Reference } \\
\text { Biogas Capacity in } \\
\text { Year } 2015 \text { (US \$) }\end{array}$ & $\begin{array}{l}\text { Investment } \\
\text { Cost for New } \\
\text { Biogas Capacity } \\
\text { for Year } 2015 \\
\quad(\text { US \$) } \\
\text { d }\end{array}$ & $\begin{array}{l}\text { Annualised } \\
\text { Capital Cost } \\
\text { for Year } \\
2019 \text { (US \$) }\end{array}$ & $\begin{array}{c}\text { Unit } \\
\text { Cleaning } \\
\text { Cost (US } \\
\$ / \mathrm{m}^{3} \text {-biogas) }\end{array}$ \\
\hline $\begin{array}{l}\text { In-situ } \\
\text { chemical } \\
\text { dosing }\end{array}$ & 72,000 & 0 & 0 & 0 & 0 & 0.0100 \\
\hline $\begin{array}{c}\text { In-situ } \\
\text { microaeration }\end{array}$ & 24,488 & $69,670.95$ & $142,825.46$ & $521,309.35$ & 9189.517 & 0.0161 \\
\hline
\end{tabular}

${ }^{\text {a }}$ Operating cost estimate per year for desulphurisation of biogas at capacity of $1000 \mathrm{~m}^{3} / \mathrm{h}$ for a system operating for $7200 \mathrm{~h} / \mathrm{y}$; ${ }^{\mathrm{b}}$ Inside battery limit (ISBL) cost estimate for desulphurisation of biogas at feed rate of $157.3 \mathrm{~m}^{3} / \mathrm{h}$, year 2015 assuming a year operation duration of $7200 \mathrm{~h}$; ${ }^{\mathrm{C}}$ Total investment cost estimate for desulphurisation of biogas at feed rate of $157.3 \mathrm{~m}^{3} / \mathrm{h}$, year 2015 assuming a year operation duration of $7200 \mathrm{~h}$; ${ }^{\mathrm{d}}$ Total investment cost estimate for desulphurisation of biogas at feed rate of $1000 \mathrm{~m}^{3} / \mathrm{h}$, year 2015 assuming a year operation duration of $7200 \mathrm{~h}$.

Table 6. Estimated annualised capital cost, annual operating cost and unit desulphurisation cost for desulphurisation technologies of the use of chelating irons, bioscrubbers, biofilters, biotrickling filters, adsorption, and absorption methods.

\begin{tabular}{|c|c|c|c|}
\hline $\begin{array}{l}\text { Desulphurisation } \\
\text { Method }\end{array}$ & $\begin{array}{c}\text { Annualised Capital } \\
\text { Cost (US \$) }^{a}\end{array}$ & Annual Operating Cost & $\begin{array}{l}\text { Unit Desulphurisation } \\
\left.\text { Cost (US } \$ / \mathrm{m}^{3}\right)\end{array}$ \\
\hline Chelating iron & $1,260,362.64$ & 504,000 & 0.245 \\
\hline Bioscrubbers & $1,186,223.66$ & 144,000 & 0.185 \\
\hline Biofilter & $667,250.81$ & 216,000 & 0.123 \\
\hline Biotrickling filters & $10,972,568.89$ & 72,000 & 1.534 \\
\hline Absorption & $17,304,037.70$ & 129,600 & 2.421 \\
\hline Adsorption & $8,896,677.48$ & 64,800 & 1.245 \\
\hline
\end{tabular}

It is immediately clear from Tables 5 and 6 that biogas desulphurisation via in-situ oxidation of dissolved sulphides via in-situ chemical dosing, for the base case scenario, constitutes the cheapest desulphurisation strategy. However, recognising the risk of variations in the estimated unit desulphurisation cost due to uncertainties in the underlying assumptions incorporated in estimating the annualised capital and operation cost, Monte Carlo simulations have been undertaken, as discussed in Section 2 above. The results are presented in Figure 5.

Figure 5 shows the unit costs for different desulphurisation technologies investigated in the present study. It shows that the unit desulphurisation cost associated with in-situ chemical dosing (CD) and microaeration (MA) approaches are estimated to be the cheapest and second cheapest approaches, with their estimated median unit desulphurisation costs of US $\$ 0.01 / \mathrm{m}^{3}$ and US $\$ 0.015 / \mathrm{m}^{3}$, the unit costs of which range between US $\$ 0.003 / \mathrm{m}^{3}$ and US $\$ 0.004 / \mathrm{m}^{3}$, respectively. The low unit desulphurisation of $\mathrm{CD}$ is consistent with a previous study where reduced capital, maintenance, and repair costs were identified as significant advantages of the CD approach compared to other 'post-digestion' biogas scrubbing desulphurisation approaches [156]. It must however be emphasised that, as stated earlier, the introduction of chemicals into the digester to minimise $\mathrm{H}_{2} \mathrm{~S}$ formation may also present negative effects on microbial activity, leading to diminishing biogas yields. In addition to possible challenges of diminished microbial activities due to the introduction of chemicals to the digester, there may be additional environmental costs associated with the disposal of the resulting sludge containing $\mathrm{Fe}^{2+}$ and $\mathrm{Fe}^{3+}$ compounds in surrounding land. This is because although iron (i.e., $\mathrm{Fe}^{2+}$ and $\mathrm{Fe}^{3+}$ ) constitutes an essential nutrient for plants, excessive amounts in soil may have toxic effects on plants due to its accumulation within plant cells [157]. The higher cost of the MA desulphurisation method 
compared to the $\mathrm{CD}$ method may be due to the additional cost associated with the purchase of auxiliary technologies, such as pumps for oxygen and air supply. Additionally, some studies have suggested the possibility of negative effects on biogas yields, due to the deterioration of the methanogenic activity of obligatory microbes necessary for biomethane production $[42,87,88]$. The possibility of these negative effects was however contradicted in studies presented in [158-160]. These contradictory observations suggest that the negative effect on biogas yields may depend on several factors, such as the level of oxygen tolerance by the methanogens present and the nature of the sludge substrate (i.e., granular or flocculent) [42]. This is because the sludge type may also influence the level of exposure of the methanogens to oxygen [42].

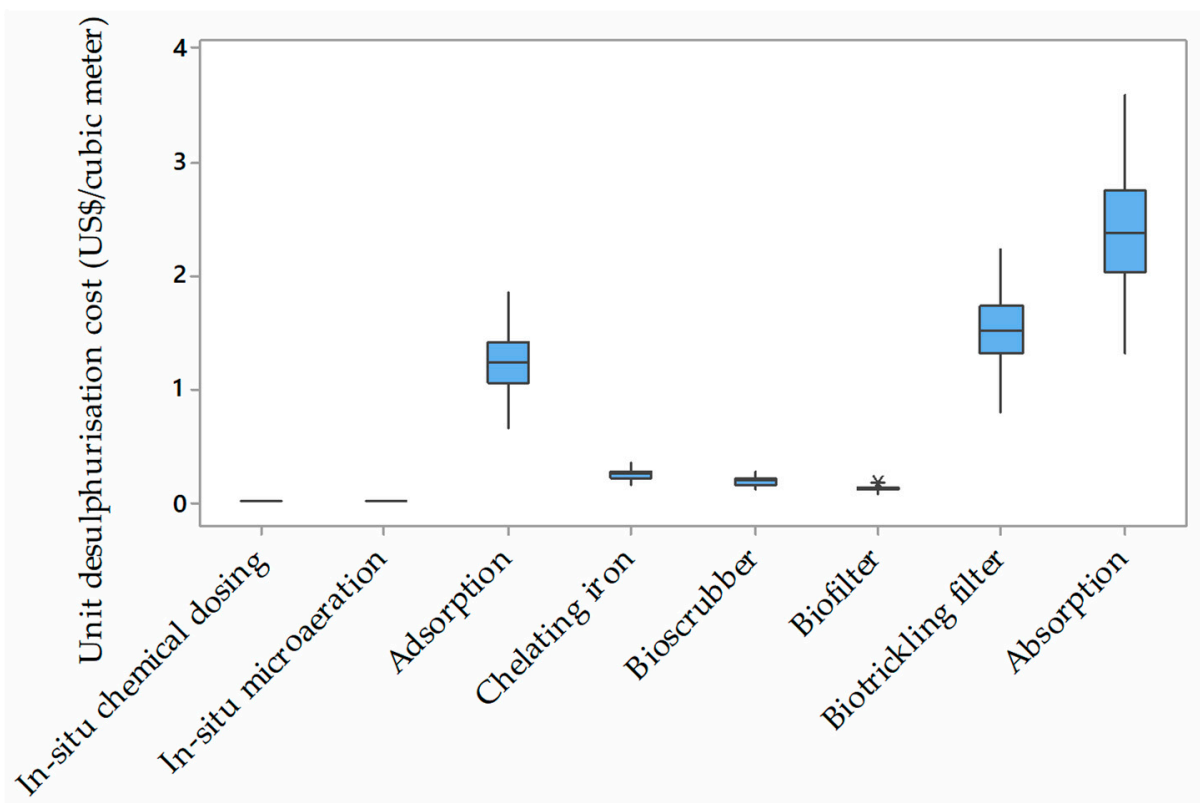

Figure 5. The unit desulphurisation cost distribution for technologies investigated in this paper. The mean unit desulphurisation cost of the desulphurisation technologies were investigated and their associated standard deviation are also presented. These values have been estimated for $50 \%$ to $150 \%$ changes in the estimated operating cost and capital cost components.

Figure 5 also shows that the traditional absorption desulphurisation strategy using $\mathrm{NaOH}$ constitutes the most expensive desulphurisation strategy, with a median unit cost of US $\$ 2.38 / \mathrm{m}^{3}$, which is about 10 times the cost of $\mathrm{H}_{2} \mathrm{~S}$ absorption using the chelating iron, which presents an estimated median unit cost of US $\$ 0.244 / \mathrm{m}^{3}$. This high cost may explain why this approach is, at present, rarely employed as a viable desulphurisation strategy [53]. In addition to the high cost of traditional absorbers using $\mathrm{NaOH}$, a high technical requirement is necessary to handle the caustic $(\mathrm{NaOH})$ solution and manage associated secondary pollution challenges, since $\mathrm{NaOH}$ is typically not regenerated from its $\mathrm{Na}_{2} \mathrm{~S}$ and $\mathrm{NaHS}$ reaction products. The unit desulphurisation cost of the adsorption system is estimated as the third most expensive desulphurisation strategy with a median cost of US $\$ 1.231 / \mathrm{m}^{3}$. The high unit desulphurisation cost estimated may be due to the cost incurred from the regular replacement of adsorbents as a result of clogging issues. This unit cost may be the reason for its preferred utilisation in desulphurisation operations when the concentration of the $\mathrm{H}_{2} \mathrm{~S}$ in the biogas is relatively low [73]. Interestingly, Figure 5 also shows significant overlap the unit desulphurisation costs of the adsorption and biotrickling filter technologies. This overlap is emphasised when it is observed that the highest possible cost (the whiskers) using the adsorption system of US $\$ 1.842 / \mathrm{m}^{3}$ exceeds the median cost using the adsorption system of US $\$ 1.52 / \mathrm{m}^{3}$. This observation may suggest a close competition between the desulphurisation strategies of adsorption and biotrickling filter technologies based on strictly economic measures. 
A comparison of the unit desulphurisation costs using biotrickling filters (BTFs), biofilters (BFs) and bioscrubbers (BS) shows that the BF system is the cheapest desulphurisation strategy. This observation is not unexpected since BF presents a simple design, composed of a fixed bed, equipped with cheap bedding materials and easily acquired microbes. On the other hand, the high median unit cost estimated as US $\$ 1.52 / \mathrm{m}^{3}$ for desulphurisation operations using biotrickling filters may be reflective of the additional cost required to sustain nutrient supply via the use of auxiliary trickling systems.

\section{Noteworthy Considerations}

As a note of caution, it is crucial to recognise that although the present study has presented the in-situ chemical dosing desulphurisation strategy as the most economically favorable approach, as illustrated by its low median unit desulphurisation cost of US $\$ 0.01 / \mathrm{m}^{3}$, several factors may impede its global acceptance. Some of these factors may include challenges of maintaining a supply of chemicals to the digester if the $\mathrm{H}_{2} \mathrm{~S}$ oxidation process is to be sustained, possible negative effects on the biogas potential, and the risk of potentially negative environmental outcomes from the disposal of the sludge residues containing insoluble metallic precipitates (i.e., FeS). Logic may however suggest that this desulphurisation approach will be preferred when a small-scale desulphurisation operation requiring high rates of production of $\mathrm{H}_{2} \mathrm{~S}$-free biogas is necessary. In such a small-scale operation, the associated chemical cost and unfavourable environmental implications may not be considered significant enough to discourage its application. In other cases, the peculiar properties of the biogas being desulphurised may influence the selection of the appropriate technology to be employed. For instance, for cases involving the desulphurisation of biogas containing low concentrations of $\mathrm{H}_{2} \mathrm{~S}$, it may be more practical to implement the desulphurisation process using adsorbents. Also, in the absence of sufficient headspace in the digester, it is not uncommon for the utilisation of biotrickling filters to be preferred to the utilisation of in-situ microaeration, even though biotrickling filters constitute a more expensive approach [15].

Beyond economics, performance, and environmental impact considerations, another factor that may be considered in the selection of the appropriate desulphurisation technology to be employed may be their life cycle impacts, as investigated in the study of [161]. Clearly, therefore, the selection of the appropriate desulphurisation strategy may depend on not only a consideration of the economic performance of the different strategies, but also their respective capabilities to satisfy peculiar design concerns, such as environmental and desulphurisation efficiency performances. It may therefore be prudent to incorporate some form of decision support system, as proposed in Ref. [162], more so if the comparative economic performances of the desulphurisation technologies do not constitute the only design selection criterion.

In another approach, the integration of several desulphurisation strategies may be preferable to the use of a single desulphurisation approach, since such an integration will facilitate the incorporation of strengths while limiting the weaknesses of the component desulphurisation strategies of the different strategies. For instance, the utilisation of an iron sponge composed of $\mathrm{Fe}_{2} \mathrm{O}_{3}$ for chemical oxidation of $\mathrm{HS}^{-}$and inoculated with thiobacteria for biological oxidation of $\mathrm{H}_{2} \mathrm{~S}$ may serve to reduce the mass of metallic precipitates generated, while also ensuring that the desulphurisation process is achieved in a short time.

\section{Conclusions}

Recognising the negative implications of high $\mathrm{H}_{2} \mathrm{~S}$ content in biogas on human health, environmental outcomes, and energy equipment durability, existing desulphurisation strategies were qualitatively and quantitative reviewed. Preliminary work based on data obtained from the literatures suggested that the in-situ chemical dosing approach constituted the cheapest biogas desulphurisation technique, even after underlying uncertainties in the estimates were incorporated. Concerns are however raised with respect to system control costs and environmental costs, more so as continued supply of chemicals may be required for sustained desulphurisation and secondary 
pollution generation concerns, respectively. Finally, recognising that each desulphurisation approach considered may present different advantages and disadvantages, the integration of several technologies was proposed as an approach to counter the individual weaknesses of desulphurisation strategies, while also combining their strengths.

Author Contributions: Conceptualisation, Z.S. and O.V.O.; Methodology, O.V.O. and Z.S.; Writing-Original Draft Preparation, O.V.O. and Z.S.; Writing-Review and Editing, O.V.O. and Z.S.

Funding: This research received no external funding.

Conflicts of Interest: The authors declare no conflict of interest.

\section{References}

1. Okoro, O.V.; Sun, Z.; Birch, J. Catalyst-Free Biodiesel Production Methods: A Comparative Technical and Environmental Evaluation. Sustainability 2018, 10, 127. [CrossRef]

2. Okoro, O.V.; Sun, Z.; Birch, J. Techno-Economic Assessment of a Scaled-Up Meat Waste Biorefinery System: A Simulation Study. Materials 2019, 12, 1030. [CrossRef] [PubMed]

3. Tyagi, V.K.; Lo, S.-L. Energy and Resource Recovery from Sludge: Full-Scale Experiences. In Environmental Materials and Waste: Resource Recovery and Pollution Prevention; Academic Press: New York, NY, USA, 2016; pp. 221-244.

4. Farida, H.; Chang, Y.L.; Hirotsugu, K.; Abdul, A.H.; Yoichi, A.; Takeshi, Y.; Hiroyuki, D. Treatment of Sewage Sludge Using Anaerobic Digestion in Malaysia: Current State and Challenges. Front. Energy Res. 2019, 7, 19. [CrossRef]

5. Okoro, O.V.; Sun, Z.; Birch, J. Prognostic assessment of the viability of hydrothermal liquefaction as a post-resource recovery step after enhanced biomethane generation using co-digestion technologies. Appl. Sci. 2018, 8, 2290. [CrossRef]

6. Dinel, H.; Mathur, S.P.; Brown, A.; Lévesque, M. A Field Study of the Effect of Depth on Methane Production in Peatland Waters: Equipment and Preliminary Results. J. Ecol. 1988, 76, 1083-1091. [CrossRef]

7. Stams, A.J.M.; Elferink, S.J.W.H.O.; Westermann, P. Metabolic interactions between methanogenic consortia and anaerobic respiring bacteria. Adv. Biochem. Eng. Biotechnol. 2003, 81, 31-56. [PubMed]

8. Dai, Q.J.; Yi, L.I.; Fang, X.J. Review of desulfurization process for biogas. IOP Conf. Ser. Earth Environ. Sci. 2017, 100, 1-7.

9. Mackie, R.I.; Stroot, P.G.; Varel, V.H. Biochemical identification and biological origin of key odor components in livestock waste. J. Anim. Sci. 1998, 76, 1331-1342. [CrossRef]

10. Scheerer, U.; Haensch, R.; Mendel, R.R.; Kopriva, S.; Rennenberg, H.; Herschbach, C. Sulphur flux through the sulphate assimilation pathway is differently controlled by adenosine $5^{\prime}$-phosphosulphate reductase under stress and in transgenic poplar plants overexpressing $\gamma$-ECS, SO, or APR. J. Exp. Biol. 2009, 61, 609-622. [CrossRef]

11. Haghighatafshar, S. Management of $\mathrm{H}_{2} \mathrm{~S}$ in Ananerobic Digestion of Enzyme Pretreated Macro Algae; Lund University: Lund, Sweden, 2012.

12. Fardeau, M.L.; Ollivier, B.; Patel, B.K.C.; Dwivedi, P.; Ragot, M.; Garcia, J.L. Isolation and characterization of a thermophilic sulfate-reducing bacterium, Desulfotomaculum thermosapovorans sp. nov. Int. J. Syst. Evol. Microbiol. 1995, 45, 218-221. [CrossRef]

13. Goorissen, H.P.; Boschker, H.T.S.; Stams, A.J.M.; Hansen, T.A. Isolation of thermophilic Desulfotomaculum strains with methanol and sulfite from solfataric mud pools, and characterization of Desulfotomaculum solfataricum sp. nov. Int. J. Syst. Evol. Microbiol 2003, 53, 1223-1229. [CrossRef] [PubMed]

14. Stefanie, J.O.E.; Visser, A.; Pol, L.W.H.; Stams, A.J.M. Sulfate Reduction in Methanogenic Bioreactors. FEMS Microbiol. Rev. 1994, 15, 119-136.

15. Khoshnevisan, B.; Tsapekos, P.; Alfaro, N.; Díaz, I.; Fdz-Polanco, M.; Rafiee, S.; Angelidaki, I. A review on prospects and challenges of biological $\mathrm{H}_{2} \mathrm{~S}$ removal from biogas with focus on biotrickling filtration and microaerobic desulfurization. Biofuel Res. J. 2017, 16, 741-750. [CrossRef]

16. Sela-Adler, M.; Ronen, Z.; Herut, B.; Antler, G.; Vigderovich, H.; Eckert, W.; Sivan, O. Co-existence of Methanogenesis and Sulfate Reduction with Common Substrates in Sulfate-Rich Estuarine Sediments. Front. Microbiol. 2017, 8, 766. [CrossRef] [PubMed] 
17. Enning, D.; Garrelfs, J. Corrosion of Iron by Sulfate-Reducing Bacteria: New Views of an Old Problem. Appl. Environ. Microbiol. 2014, 80, 1226-11236. [CrossRef] [PubMed]

18. Fauque, G.; Ollivier, B. Anaerobes: The sulphate-reducing bacteria as an example of metabolic diversity. In Microbial Diversity and Bioprospecting; ASm Press: Washington, DC, USA, 2004.

19. Hills, A.G. pH and the Henderson-Hasselbalch equation. Am. J. Med. 1973, 55, 131-133. [CrossRef]

20. Verma, N.K.; Khanna, S.K.; Kapila, B. Comprehensive Chemistry; Laxmi: New Delhi, India, 2010.

21. WHO. Hydrogen sulfide. In Air Quality Guidelines for Europe Second Edition; World Health Organisation: Copenhagen, Denmark, 2010; pp. 146-148.

22. Chaiprapat, S.; Charnnok, B.; Kantachote, D.; Sung, S. Bio-desulfurization of biogas using acidic biotrickling filter with dissolved oxygen in step feed recirculation. Bioresour. Technol. 2015, 179, 429-435. [CrossRef]

23. Horikawa, M.S.; Rossi, F.; Gimenes, M.L.; Costa, C.M.M.; Silva, M.G.C. chemical absorption of $\mathrm{H}_{2} \mathrm{~S}$ for biogas purification. Braz. J. Chem. Eng. 2004, 21, 415-422. [CrossRef]

24. Bai, Y.; Bai, Q. Subsea Corrosion and Scale. In Subsea Engineering Handbook, 2nd ed.; Gulf Professional Publishing: Oxford, UK, 2019; pp. 455-487.

25. CEN. Standard in Development: BS EN 16723-2 Natural Gas and Biomethane for Use in Transport and Biomethane for Injection in the Natural Gas Network Part 2: Automotive Fuel Specifications; European Commitee for Standardisation: Stockholm, Sweden, 2017.

26. Denyer, D.; Tranfield, D. The Sage Handbook of Organizational Research Methods; Sage: London, UK, 2009; pp. 671-689.

27. Müller-Langer, F.; Majer, S.; O'Keeffe, S. Benchmarking biofuels-A comparison of technical, economic and environmental indicators. Energy Sustain. Soc. 2014, 4, 1-14. [CrossRef]

28. Okoro, V.O. Scaled-Up Biodiesel Production from Meat Processing Dissolved Air Flotation Sludge: A Simulation Study. AgriEngineering 2019, 1, 17-43. [CrossRef]

29. Jenkins, S. Chemical Engineering Plant Cost Index: 2018 Annual Value. Available online: https://www. chemengonline.com/2019-cepci-updates-january-prelim-and-december-2018-final/ (accessed on 29 May 2019).

30. Turton, R.C.B.; Whiting, W.B.; Shaeiwitz, J.A. Analysis Synthesis and Design of Chemical Processes; Prentice Hall: Upper Saddle River, NJ, USA, 2009.

31. Michailos, S.; McCord, S.; Sick, V.; Stokes, G.; Styring, P. Dimethyl ether synthesis via captured $\mathrm{CO}_{2}$ hydrogenation within the power to liquids concept: A techno-economic assessment. Energy Convers. Manag. 2019, 184, 262-276. [CrossRef]

32. Díaz, I.; Ramos, I.; Fdz-Polanco, M. Economic analysis of microaerobic removal of $\mathrm{H}_{2} \mathrm{~S}$ from biogas in full-scale sludge digesters. Bioresour. Technol. 2015, 192, 280-286. [CrossRef] [PubMed]

33. Deshusses, M.A.; Webster, T.S. Construction and Economics of a Pilot/Full-Scale Biological Trickling Filter Reactor for the Removal of Volatile Organic Compounds from Polluted Air. J. Air Waste Manag. Assoc. 2011, 50, 1947-1956. [CrossRef]

34. Nägele, H.J.; Steinbrenner, J.; Hermanns, G.; Holstein, V.; Haag, N.L.; Oechsner, H. Innovative additives for chemical desulphurisation in biogas processes: A comparative study on iron compound products. Biochem. Eng. J. 2017, 121, 181-187. [CrossRef]

35. Erdirencelebi, D.; Kucukhemek, M. Control of $\mathrm{H}_{2} \mathrm{~S}$ in full-scale anaerobic digesters using iron(III) chloride: Performance, origin and effects. Water SA 2018, 44, 176-183. [CrossRef]

36. Schäfer, F.; Dittrich-Zechendorf, M.; Leiker, M.; Pröter, J. Powdery ferric compounds for biogas process desulphurisation. Landtechnik 2017, 72, 39-48.

37. KRONOS. Hydrogen Sulfide Elimination from Biogas; KRONOS International Inc.: Dallas, TX, USA, 2014.

38. Jiang, H.; Li, T.; Stinner, W.; Nie, H. Selection of in-situ Desulfurizers for Chicken Manure Biogas and Prediction of Dosage. Pol. J. Environ. Stud. 2017, 26, 155-161. [CrossRef]

39. SevernWye. Introduction to Production of Biomethane from Biogas: A Guide for England and Wales; SevernWye Agency: Bangor, Wales, 2017.

40. Lupitskyy, R.; Alvarez-Fonseca, D.; Herde, Z.D.; Satyavolu, J. In-situ prevention of hydrogen sulfide formation during anaerobic digestion using zinc oxide nanowires. J. Environ. Chem. Eng. 2018, 6, 110-118. [CrossRef]

41. Allegue, L.B.; Hinge, J.H. Biogas Upgrading Evaluation for $\mathrm{H}_{2} \mathrm{~S}$ Removal; Danish Technology Institute: Taastrup, Denmark, 2014. 
42. Krayzelova, L.; Bartacek, J.; Díaz, I.; Jeison, D.; Volcke, E.I.P.; Jenicek, P. Microaeration for hydrogen sulfide removal during anaerobic treatment: A review. Rev. Environ. Sci. Biotechnol. 2015, 14, 703-725. [CrossRef]

43. NYSERDA. Assessment of Biochemical Process Controls for Reduction of Hydrogen Sulfide Concentrations in Biogas from Farm Digesters; New York State Energy Research and Development Authority: New York, NY, USA, 2012.

44. Smith, J.A.; Carliell-Marquet, C.M. The digestibility of iron-dosed activated sludge. Bioresour. Technol. 2008, 99, 8585-8592. [CrossRef]

45. Al-Imarah, K.A.; Lafta, T.M.; Jabr, A.K.; Mohammad, A.N. Desulfurization for Biogas Generated by Lab Anaerobic Digestion unit. J. Agric. Vet. Sci. 2017, 10, 2319-2372.

46. Ofverstrom, S.; Dauknys, R.; Sapkaite, I. The effect of iron salt on anaerobic digestion and phosphate release to sludge liquor. Environ. Prot. Eng. 2011, 3, 123-126.

47. Khanal, S.K.; Huang, J. Online Oxygen Control for Sulfide Oxidation in Anaerobic Treatment of High-Sulfate Wastewater. Water Environ. Res. 2006, 78, 397-408. [CrossRef] [PubMed]

48. Awe, O.W.; Zhao, Y.; Nzihou, A.; Minh, D.P.; Lyczko, N. A Review of Biogas Utilisation, Purification and Upgrading Technologies. Waste Biomass Valoris. 2017, 8, 267-283. [CrossRef]

49. Lein, C.; Wang, M.; Lin, W. Study on the removal of $\mathrm{H}_{2} \mathrm{~S}$ from biogas biomaterial using water scrubbing. Trans. Tech. Publ. 2017, 723, 599-603.

50. ToolBox, E. Solubility of Gases in Water. 2008. Available online: https://www.engineeringtoolbox.com/gasessolubility-water-d_1148.html (accessed on 23 April 2019).

51. Nie, H.; Jiang, H.; Chong, D.; Wu, Q.; Xu, C.; Zhou, H. Comparison of Water Scrubbing and Propylene Carbonate Absorption for Biogas Upgrading Process. Energy Fuels 2013, 27, 3239-3245. [CrossRef]

52. Dyment, J.; Watanasiri, S. Acid Gas Cleaning Using DEPG Physical Solvents: Validation with Experimental and Plant Data; Aspentech: Bedford, UK, 2015.

53. Petersson, A.; Wellinger, A. Biogas Upgrading Technologies-Developments and Innovations. Task 37-Energy from Biogas and Landfill Gas; EA Bioenergy: Aadorf, Switzerland, 2009.

54. Deshmukh, G.M.; Shete, A.; Pawar, D.M. Oxidative Absorption of Hydrogen Sulfide using Iron-chelate Based Process: Chelate Degradation. J. Anal. Bioanal. Tech. 2012, 3, 138. [CrossRef]

55. Frare, L.; Vieira, M.; Silva, M.; Pereira, N.; Gimenes, M. Hydrogen Sulfide Removal from Biogas Using Fe/EDTA Solution: Gas/Liquid Contacting and Sulfur Formation. Environ. Prog. Sustain. Energy 2009, 29, 34-41. [CrossRef]

56. Neumann, D.W.; Lynn, S. Oxidative absorption of $\mathrm{H}_{2} \mathrm{~S}$ and $\mathrm{O}_{2}$ by iron chelate solutions. Am. Inst. Chem. Eng. 1984, 30, 62-69. [CrossRef]

57. Maia, D.C.S.; Niklevicz, R.R.; Arioli, R.; Frare, L.M.; Arroyo, P.A.; Gimenes, M.L.; Pereira, N.C. Removal of $\mathrm{H}_{2} \mathrm{~S}$ and $\mathrm{CO}_{2}$ from biogas in bench scale and the pilot scale using a regenerable Fe-EDTA solution. Renew. Energy 2017, 109, 188-194. [CrossRef]

58. Krischan, J.; Makaruk, A.; Harasek, M. Design and scale-up of an oxidative scrubbing process for the selective removal of hydrogen sulfide from biogas. J. Hazard. Mater. 2012, 215, 49-56. [CrossRef] [PubMed]

59. Coppola, G.; Papurello, D. Biogas Cleaning: Activated Carbon Regeneration for $\mathrm{H}_{2} \mathrm{~S}$ Removal. Clean Technol. 2018, 1, 40-57. [CrossRef]

60. Magomnang, A.S.M.; Villanueva, E.P. Removal of Hydrogen Sulfide from Biogas using Dry Desulfurization Systems. In Proceedings of the International Conference on Agricultural, Environmental and Biological Sciences, Phuket, Thailand, 24-25 April 2014.

61. UNIDO. Biogas to Biomethane. 2017. Available online: https://www.biogas-to-biomethane.com/Download/ BTB.pdf (accessed on 30 April 2019).

62. Cherif, H. Study and Modeling of Separation Methods H2S from Methane, Selection of a Method Favoring H2S Valorization; PSL Research University: Paris, France, 2016.

63. Rocca, M.A. Surface Science and Nanostructuring/Adsorption at Surfaces. 2012. Available online: http://www.fisica.unige.it/ \{\}rocca/Didattica/Surface $\% 20$ Science $\% 20$ and $\% 20$ Nanostructuring/6\% 20adsorption\%20at\%20surfaces.pdf (accessed on 30 April 2019).

64. Al Mamun, M.R.; Torii, S. Removal of Hydrogen Sulfide $\left(\mathrm{H}_{2} \mathrm{~S}\right)$ from Biogas Using Zero-Valent Iron. J. Clean Energy Technol. 2015, 3, 428-432. [CrossRef] 
65. Sitthikhankaew, R.; Predapitakkun, S.; Kiattikomol, R.; Pumhiran, S.; Assabumrungrat, S.; Laosiripojana, N. Comparative Study of Hydrogen Sulfide Adsorption by using Alkaline Impregnated Activated Carbons for Hot Fuel Gas Purification. Energy Procedia 2011, 9, 15-24. [CrossRef]

66. Louhichi, S.; Ghorbel, A.; Takfaoui, A.; Chekir, H.; Trabelsi, N.; Khemakhem, S. Alkaline activated carbon as adsorbents of hydrogen sulfide gases from chimney of phosphoric units. J. Mater. Environ. Sci. 2018, 9, 2686-2691.

67. Kwaśny, J.; Balcerzak, W.; Rezka, P. Application of zeolites for the adsorptive biogas desulfurisation. Tech. Trans. Environ. Eng. 2015, 39-45. [CrossRef]

68. Micoli, L.; Bagnasco, G.; Turco, M. $\mathrm{H}_{2} \mathrm{~S}$ removal from biogas for fuelling MCFCs: New adsorbing materials. Int. J. Hydrog. Energy 2014, 39, 1783-1787. [CrossRef]

69. Feldbauer, S.L. Steam Treating; Enhancing the Surface Properties of Metal Components; Aabbott Furnace Company: St. Marys, PA, USA, 2003.

70. Wang, D. Breakthrough Behavior of H2S Removal with an Iron Oxide Based CG-4 Adsorbent in a Fixed-Bed Reactor; University of Saskatchewan: Saskatoon, SK, Canada, 2008.

71. Raabe, T.; Erler, R.; Kureti, S.; Krause, H. Oxygen Removal during Biogas Upgrading using iron-based Adsorbents. In Proceedings of the International Gas Union Research Conference, Copenhagen, Denmark, 17-19 September 2014.

72. Pourzolfaghar, H.; Ismail, M.; Izhar, S.; MagharehEsfahan, Z. Review of $\mathrm{H}_{2} \mathrm{~S}$ Sorbents at Low-Temperature Desulfurization of Biogas. Int. J. Chem. Environ. Eng. 2004, 5, 22-28.

73. TVT. Biogas to Biomethane Technology Review; Vienna University of Technology: Vienna, Austria, 2012.

74. Huertas, J.I.; Giraldo, N.; Izquierdo, S. Removal of H2S and CO2 from Biogas by Amine Absorption, Mass Transfer in Chemical Engineering Processes; InTech: Rijeka, Croatia, 2011.

75. Paolini, V.; Petracchini, F.; Guerriero, E.; Bencini, A.; Drigo, S. Biogas cleaning and upgrading with natural zeolites from tuffs. Environ. Technol. 2016, 37, 1418-1427. [CrossRef] [PubMed]

76. Thanapong, D. Micro-Aeration for Hydrogen Sulfide Removal from Biogas; Iowa State University: Iowa Ames, IA, USA, 2009.

77. Tang, Y.; Shigematsu, T.; Morimura, S.I.; Kida, K. The effects of micro-aeration on the phylogenetic diversity of microorganisms in a thermophilic anaerobic municipal solid-waste digester. Water Res. 2004, 38, 2537-2550. [CrossRef] [PubMed]

78. Li, Y.; Qiao, W. Transformations and impacts of ammonia and $\mathrm{H}_{2} \mathrm{~S}$ in anaerobic digestion reactors. In Ananerobic Biotechnology: Environmental Protection and Resource Recovery; Imperial College Press: London, UK, 2015; pp. 109-133.

79. Huber, B.; Herzog, B.; Drewes, J.E.; Koch, K.; Müller, E. Characterization of sulfur oxidizing bacteria related to biogenic sulfuric acid corrosion in sludge digesters. BMC Microbiol. 2016, 16, 153. [CrossRef] [PubMed]

80. Kleinjan, W. Biologically Produced Sulphur Particles and Polysulphide Sulphide Ions. Effects on a Biotechnological Process for the Removal of Hydrogen suphide from Gas Streams. Ph.D. Thesis, Wageningen Universiteit, Wageningen, The Netherlands, 2005.

81. Díaz, I.; Pérez, S.I.; Ferrero, E.M.; Fernández-Polanco, F. Effect of oxygen dosing point and mixing on the microaerobic removal of $\mathrm{H}_{2} \mathrm{~S}$ in sludge digesters. Bioresour. Technol. 2011, 102, 3768-3775. [CrossRef] [PubMed]

82. Duangmanee, T. Micro-Aeration for Hydrogen Sulphide Removal from Biogas. Ph.D. Thesis, Iowa State University, Ames, IA, USA, 2009. [CrossRef]

83. Guerrero, L.; Montalvo, S.; Huiliñir, C.; Campos, J.L.; Barahona, A.; Borja, R. Advances in the biological removal of sulphides from aqueous phase in anaerobic processes: A review. Environ. Rev. 2015, 24, 84-100. [CrossRef]

84. Diaz, I.; Lopes, A.C.; Perez, S.I.; Fdz-Polanco, M. Determination of the optimal rate for the microaerobic treatment ofseveral $\mathrm{H}_{2} \mathrm{~S}$ concentrations in biogas from sludge digesters. Water Sci. Technol. 2011, 64, $233-238$. [CrossRef] [PubMed]

85. Van den Ende, F.P.; van Gemerden, H. Sulfide oxidation under oxygen limitation by a Thiobacillus thioparus isolated from a marine microbial mat. FEMS Microbiol. Ecol. 1993, 13, 69-77.

86. Jeníček, P.; Horejš, J.; Pokorná-Krayzelová, L.; Bindzar, J.; Bartáček, J. Simple biogas desulfurization by microaeration-Full scale experience. Anaerobe 2017, 46, 41-45. [CrossRef] 
87. Zitomer, D.H.; Shrout, J.D. High-sulfate, high chemical oxygen demand wastewater treatment using aerated methanogenic fluidized beds. Water Environ. Res. 2000, 72, 90-97. [CrossRef]

88. Jenicek, P.; Koubova, J.; Bindzar, J.; Zabranska, J. Advantages of anaerobic digestion of sludge in microaerobic conditions. Water Sci. Technol. 2010, 62, 427-434. [CrossRef]

89. Karhadkar, P.P.; Audic, J.; Faup, G.M.; Khanna, P. Sulfide and sulfate inhibition of methanogenesis. Water Res. 1987, 21, 1061-1066. [CrossRef]

90. Parker, M.L. Method for Removing Hydrogen Sulfide from Sour Gas and Converting It to Hydrogen and Sulfuric Acid. Ph.D. Thesis, Stanford University, Stanford, CA, USA, 1 June 2010.

91. Valdés, F.; Camiloti, P.R.; Rodriguez, R.P.; Delforno, T.P.; Carrillo-Reyes, J.; Zaiat, M.; Jeison, D. Sulfide-oxidizing bacteria establishment in an innovative microaerobic reactor with an internal silicone membrane for sulfur recovery from wastewater. Biodegradation 2016, 27, 119-130. [CrossRef]

92. Pokorna-Krayzelova, L.; Bartacek, J.; Theuri, S.N.; Gonzalez, C.A.S.; Prochazk, J.; Volcke, E.I.P.; Jenicek, P. Microaeration through a biomembrane for biogas desulfurization: Lab-scale and pilot-scale experiences. Environ. Sci. Water Res. Technol. 2018, 4, 1190-1200. [CrossRef]

93. Ramos, I.; Pérez, R.; Fdz-Polanco, M. Microaerobic desulphurisation unit: a new biological system for the removal of $\mathrm{H}_{2} \mathrm{~S}$ from biogas. Bioresour. Technol. 2013, 142, 633-640. [CrossRef] [PubMed]

94. Lópeza, L.R.; Dorado, A.D.; Mora, M.; Gamisans, X.; Lafuente, J.; Gabriel, D. Modeling an aerobic biotrickling filter for biogas desulfurization through a multi-step oxidation mechanism. Chem. Eng. J. 2016, 294, 447-457. [CrossRef]

95. Montebello, A.M.; Mora, M.; López, L.R.; Bezerra, T.; Gamisans, X.; Lafuente, J.; Baeza, M.; Gabriel, D. Aerobic desulfurization of biogas by acidic biotrickling filtration in a randomly packed reactor. J. Hazard. Mater. 2014, 280, 200-208. [CrossRef] [PubMed]

96. Barbusiński, K.; Kalemba, K. Use of biological methods for removal of $\mathrm{H}_{2} \mathrm{~S}$ from biogas in wastewater treatment plants-A review. Arch. Civ. Eng. Environ. 2016, 9, 103-112. [CrossRef]

97. Soreanu, G.; Béland, M.; Falletta, P.; Ventresca, B.; Seto, P. Evaluation of different packing media for anoxic $\mathrm{H}_{2} \mathrm{~S}$ control in biogas. Environ. Technol. 2009, 30, 1249-1259. [CrossRef] [PubMed]

98. Gabriel, D.; Cox, H.H.J.; Deshusses, M.A. Conversion of Full-Scale Wet Scrubbers to Biotrickling Filters for Control at Publicly Owned Treatment Works. J. Environ. Eng. 2004, 130, 1110-1117. [CrossRef]

99. Qiu, X.; Deshusses, M.A. Performance of a monolith biotrickling filter treating high concentrations of $\mathrm{H}_{2} \mathrm{~S}$ from mimic biogas and elemental sulfur plugging control using pigging. Chemosphere 2017, 186, 790-797. [CrossRef]

100. Tayar, S.P.; Guerrero, R.B.C.; Hidalgo, L.F.; Bevilaqua, D. Evaluation of Biogas Biodesulfurization Using Different Packing Materials. Chemengineering 2019, 3, 27. [CrossRef]

101. Devinny, J.S.; Deshusses, M.A.; Webster, T.S. Biofiltration for Air Pollution Control; CRC-Lewis Publishers: Boca Raton, FL, USA, 1999.

102. Liu, D.H.F. Environmental Engineers' Handbook; CRC Press: Boca Raton, FL, USA, 1999.

103. Webster, T.S.; Devinny, J.S. Biofiltration of Odors, Toxics and Volatile Organic Compounds from Publicly Owned Treatment Works. Environ. Prog. 1996, 15, 141-147. [CrossRef]

104. Converse, B.M.; Schroeder, E.D.; Iranpour, R.; Cox, H.H.J.; Deshusses, M.A. Odor and Volatile Organic Compound Removal from Wastewater Treatment Plant Headworks Ventilation Air Using a Biofilter. Water Environ. Res. 2003, 75, 444-454. [CrossRef] [PubMed]

105. Dumont, E. $\mathrm{H}_{2} \mathrm{~S}$ removal from biogas using bioreactors: A review. Int. J. Energy Environ. 2015, 6, 479-498.

106. Fernández, M.; Ramírez, M.; Gómez, J.M.; Cantero, D. Biogas biodesulfurization in an anoxic biotrickling filter packed with open-pore polyurethane foam. J. Hazard. Mater. 2014, 264, 529-535. [CrossRef]

107. Almenglo, F.; Bezerra, T.; Lafuente, J.; Gabriel, D.; Ramírez, M.; Cantero, D. Effect of gas-liquid flow pattern and microbial diversity analysis of a pilot-scale biotrickling filter for anoxic biogas desulfurization. Chemosphere 2016, 157, 215-223. [CrossRef] [PubMed]

108. Adams, G.M.; Hargreaves, R.; Witherspoon, J.; Ong, H.; Burrowes, P.; Easter, C.; Dickey, J.; James, F.; MacPherson, L.; Porter, R.; et al. Identifying and Controlling Municipal Wastewater Odor Phase I: Literature Search and Review; IWA publishing: Alexandria, Egypt, 2003.

109. Schiavon, M.; Ragazzi, M.; Torretta, V.; Rada, E.C. Comparison between conventional biofilters and biotrickling filters applied to waste bio-drying in terms of atmospheric dispersion and air quality. Environ. Technol. 2015, 37, 975-982. [CrossRef] 
110. Pathak, N.; Mahajan, P.V. Ethylene Removal from Fresh Produce Storage: Current Methods and Emerging Technologies. Ref. Modul. Food Sci. 2017. [CrossRef]

111. Oyarzún, P.; Arancibia, F.; Canales, C.; Aroca, G.E. Biofiltration of high concentration of $\mathrm{H}_{2} \mathrm{~S}$ using Thiobacillus thioparus. Process Biochem. 2003, 39, 165-170. [CrossRef]

112. SU, J.J.; Chen, Y.J.; Chang, Y.C. A study of pilot scale biogas bio-filter system for utilisation on pigs farms. J. Agric. Sci. 2014, 152, 217-224. [CrossRef]

113. Groenestijn, J.W.V. Biotechniques for Air Pollution Control: Past, Present and Future Trend; University of La Coruña Publisher: La Coruña, Spain, 2005.

114. Koe, L.C.C. Evaluation of a pilot-sclea bioscrubber for the removal of $\mathrm{H}_{2}$ S. Water Environ. J. 2000, 14, 432-435. [CrossRef]

115. Koutinas, M.; Peeva, L.G.; Livingston, A.G. An attempt to compare the performance of bioscrubbers and biotrickling filters for degradation of ethyl acetate in gas streams. J. Chem. Technol. Biotechnol. 2005, 80, 1252-1260. [CrossRef]

116. Van-Groenestijn, J.W. Bioscrubbers. In Bioreactors for Waste Gas Treatment. Environmental Pollution; Springer: Dordrecht, The Netherlands, 2001; pp. 133-162.

117. LeCloirec, P.; Humeau, P. Bioscrubbers. In Air Pollution Prevention and Control: Bioreactors and Bioenergy; John Wiley \& Sons: West Sussex, UK, 2013; pp. 139-153.

118. Behera, B.C.; Mishra, R.R.; Dutta, S.K.; Thatoi, H.N. Sulphur oxidising bacteria in mangrove ecosystem: A review. Afr. J. Biotechnol. 2014, 13, 2897-2907.

119. Tang, K.; Baskaran, V.; Nemati, M. Bacteria of the sulphur cycle: An overview of microbiology, biokinetics and their role in petroleum and mining industries. Biochem. Eng. J. 2009, 44, 73-94. [CrossRef]

120. Simon, J.; Kroneck, P.M.H. Chapter Two-Microbial Sulfite Respiration. In Advances in Microbial Physiology; Academic Press: Oxford, UK, 2013; pp. 45-117.

121. Lampe, D.G.; Zhang, T.C. Evaluation of sulfur-based autotrophic denitrification. In Proceedings of the Great Plains/Rocky Mountain Hazardous Substance Research Center (HSRC)/Waste-management Education \& Research Consortium (WERC) JointConference on the Environment, Albuquerque, NM, USA, 21-23 May 1996.

122. Hayakawa, A.; Hatakeyama, M.; Asano, R.; Ishikawa, Y.; Hidaka, S. Nitrate reduction coupled with pyrite oxidation in the surface sediments of a sulfide-rich ecosystem. JGR Biogeosci. 2013, 118, 639-649. [CrossRef]

123. Dolejs, P.; Paclík, L.; Maca, J.; Pokorna, D.; Zabranska, J.; Bartacek, J. Effect of S/N ratio on sulfide removal by autotrophic denitrification. Appl. Microbiol. Biotechnol. 2015, 99, 2383-2392. [CrossRef] [PubMed]

124. Soreanu, G.; Béland, M.; Falletta, P.; Ventresca, B.; Seto, P. Laboratory pilot scale study for $\mathrm{H}_{2} \mathrm{~S}$ removal from biogas in an anoxic biotrickling filter. Water Sci. 2008, 57, 201-207. [CrossRef] [PubMed]

125. Khanongnuch, R.; Di Capua, F.; Lakaniemi, A.; Rene, E.R.; Lensa, P.N.L. $\mathrm{H}_{2} \mathrm{~S}$ removal and microbial community composition in an anoxic biotrickling filter under autotrophic and mixotrophic conditions. J. Hazard. Mater. 2019, 367, 397-406. [CrossRef] [PubMed]

126. Muñoz, R.; Malhautier, L.; Fanlo, J.; Quijano, G. Biological technologies for the treatment of atmospheric pollutants. Int. J. Environ. Anal. Chem. 2015, 95, 950-967. [CrossRef]

127. López, L.R.; Dorado, A.D.; Mora, M.; Prades, L.I.; Gamisans, X.; Lafuente, J.; Gabriel, D. Modelling biotrickling filters to minimize elemental sulfur accumulation during biogas desulfurization under aerobic conditions. In Proceedings of the 7th European Meeting on Chemical Industry and Environment, Tarragona, Spain, 10-12 June 2015.

128. Mezzari, M.P.; Da Silva, M.L.B. Sulfide Removal from Biogas by Sulphur Oxidising Bacteria; Internacional Sobre Gerenciamento Deresíduos Agropecuários e Agroindustriais: SÃO Pedro, São Paulo, Brazil, 2013.

129. Syed, M.; Soreanu, G.; Falletta, P.; Béland, M. Removal of hydrogen sulfide from gas streams using biological processes-A review. Can. Biosyst. Eng. 2006, 48, 2.

130. Cork, D.; Mather, J.; Maka, A.; Srnak, A. Control of oxidative sulfur metabolism of Chlorobium limola forma thiosulfatophilum. Appl. Environ. Microbiol. 1985, 49, 269-272.

131. Pokorna, D.; Zabranska, J. Sulfur-oxidizing bacteria in environmental technology. Biotechnol. Adv. 2015, 33, 1246-1259. [CrossRef]

132. Massé, A.; Pringault, O.; Wit, R. Experimental Study of Interactions between Purple and Green Sulfur Bacteria in Sandy Sediments Exposed to Illumination Deprived of Near-Infrared Wavelengths. Appl. Environ. Microbiol. 2002, 68, 2972-2981. [CrossRef] [PubMed] 
133. Gerardi, M.H.; Lytle, B. Purple and Green Sulfur Bacteria. In The Biology and Troubleshooting of Facultative Lagoons; John Wiley \& Sons: New York, NY, USA, 2015; pp. 73-76.

134. Burns, A.S.; Padilla, C.C.; Pratte, Z.A.; Gilde, K.; Regensburger, M.; Hall, E.; Dove, A.D.M.; Stewart, F.J. Broad Phylogenetic Diversity Associated with Nitrogen Loss through Sulfur Oxidation in a Large Public Marine Aquarium. Appl. Environ. Microbiol. 2018, 84, e01250-18. [CrossRef] [PubMed]

135. Pfenning, N. Phototropic green and purple bacteria: A comparative, systematic survey. Ann. Rev. Microbiol. 1977, 31, 275-290. [CrossRef] [PubMed]

136. Nicholls, D.G.; Ferguson, S.J. Photosynthetic Generators of Protonmotive Force. In Bioenergetics, 4th ed.; Academic Press: Oxford, UK, 2013; pp. 159-196.

137. Müller, J.; Overmann, J. Close interspecies interactions between prokaryotes from sulfureous environments. Front. Microbiol. 2011, 2, 146. [CrossRef] [PubMed]

138. Robertson, L.A.; Kuenen, J.G. Denitrification by obligate and facultative autotrophs. In Autotrophic Microbiology and One-Carbon Metabolism Vol. 1; Kluwer Academic Publishers: Dordrecht, The Netherlands, 2012; pp. 93-117.

139. Rawat, R.; Rawat, S. Colorless sulfur oxidizing bacteria from diverse habitats. Adv. Appl. Sci. Res. 2015, 6, 230-235.

140. Canfield, D.E.; Kristensen, E.; Thamdrup, B. The Sulfur Cycle. In Advances in Marine Biology; Academic Press: Cambridge, MA, USA, 2005; pp. 313-381.

141. Barak, Y.; Tal, Y.; Rijn, J. Light-Mediated Nitrite Accumulation during Denitrification by Pseudomonas sp. Strain JR12. Appl. Environ. Microbiol. 1998, 64, 813-817.

142. Qambrani, N.A.; Oh, S. Effect of Dissolved Oxygen Tension and Agitation Rates on Sulfur-Utilizing Autotrophic Denitrification: Batch Tests. Appl. Biochem. Biotechnol. 2013, 169, 181-191. [CrossRef]

143. Kuenen, J.G.; Robertson, L.A.; Gemerden, H. Microbial Interactions among Aerobic and Anaerobic Sulfur-Oxidizing Bacteria. In Advances in Microbial Ecology: Volume 8; Springer: Boston, MA, USA, 1985; pp. 1-54.

144. Gemerden, H. Production of elemental sulfur by green and purple sulfur bacteria. Arch. Microbiol. 1986, 146, 52-56. [CrossRef]

145. Holkenbrink, C.; Barbas, S.O.; Mellerup, A.; Otaki, H.; Frigaard, N.U. Sulfur globule oxidation in green sulfur bacteria is dependent on the dissimilatory sulfite reductase system. Microbiology 2011, 157, 1229-1239. [CrossRef]

146. Fenchel, T.; King, G.M.; Blackburn, T.H. Aquatic Sediments. In Bacterial Biogeochemistry, 3rd ed.; Elsevier: London, UK, 2012; pp. 121-142.

147. Garrido, M.M. Characterisation of S-Oxidising Biomass through Respirametric Techniques under Anoxic and Aerobic Conditions; Univesitat Autonoma de Barcelona: Barcelona, Spain, 2014.

148. Pringault, O.; Kuhlt, M.; Wit, R.; Caumettel, P. Growth of green sulphur bacteria in experimental benthic oxygen, sulphide, $\mathrm{pH}$ and light gradients. Microbiology 1998, 144, 1051-1061. [CrossRef]

149. Bharathi, P.A.L. Sulfur Cycle. In Encyclopedia of Ecology; Academic Press: Oxford, UK, 2008; pp. 3424-3431.

150. Mahmood, Q.; Zheng, P.; Cai, J.; Wu, D.; Hu, B.; Li, J. Anoxic sulfide biooxidation using nitrite as electron acceptor. J. Hazard. Mater. 2007, 147, 249-256. [CrossRef] [PubMed]

151. Wahlund, T.M.; Tabita, F.R. The reductive tricarboxylic acid cycle of carbon dioxide assimilation: initial studies and purification of ATP-citrate lyase from the green sulfur bacterium Chlorobium tepidum. J. Bacteriol. 1997, 179, 4859-4867. [CrossRef] [PubMed]

152. Rothschild, L.J. The evolution of photosynthesis.again? Phil. Trans. R. Soc. B 2008, 363, 2787-2801. [CrossRef] [PubMed]

153. Kuenen, J.G. Colourless sulphur bacteria and their role in the sulphur cycle. Plant Soil 1975, 43, 49-76. [CrossRef]

154. Okafor, N. Environmental Microbiology of Aquatic and Waste Systems; Springer Science: Asheville, NC, USA, 2011.

155. Chemengonline. Economic Indicators. Available online: https://www.chemengonline.com/mediakit/wpcontent/uploads/2016/01/EconomicIndicatorSampleSept17.pdf (accessed on 29 May 2019).

156. Shelford, T.; Gooch, C.; Choudhury, A.; Lansing, S. A Technical Reference Guide for Dairy-Derived Biogas Production, Treatment and Utilization. 2019. Available online: https://enst.umd.edu/sites/enst.umd.edu/ files/_docs/FarmerbiogashandbookFinal.pdf (accessed on 20 July 2019). 
157. Connolly, E.L.; Guerinot, M.L. Iron stress in plants. Genome Biol. 2002, 3. [CrossRef]

158. Fdz-Polanco, M.; Diaz, I.; Perez, S.I.; Lopes, A.C.; Fdz-Polanco, F. $\mathrm{H}_{2} \mathrm{~S}$ removal in the anaerobic digestion of sludge by micro-aerobic processes: Pilot plant experience. Water Sci. Technol. 2009, 60, 3045-3050. [CrossRef] [PubMed]

159. Jenicek, P.; Celis, C.A.; Krayzelova, L.; Anferova, N.; Pokorna, D. Improving products of anaerobic sludge digestion by microaeration. Water Sci. Technol. 2014, 69, 803-809. [CrossRef] [PubMed]

160. Nghiem, L.D.; Manassa, P.D.M.; Fitzgerald, S.K. Oxidation reduction potential as a parameter to regulate micro-oxygen injection into anaerobic digester for reducing $\mathrm{H}_{2} \mathrm{~S}$ concentration in biogas. Bioresour. Technol. 2014, 173, 443-447. [CrossRef]

161. Cano, P.I.; Colón, J.; Ramírez, M.; Lafuente, J.; Gabriel, D.; Cantero, D. Life cycle assessment of different physical-chemical and biological technologies for biogas desulfurization in sewage treatment plants. J. Clean. Prod. 2018, 181, 663-674. [CrossRef]

162. Santos-Clotas, E.; Cabrera-Codony, A.; Castillo, A.; Martín, M.J.; Poch, M.; Monclus, H. Environmental Decision Support System for Biogas Upgrading to Feasible Fuel. Energies 2019, 12, 1546. [CrossRef]

(C) 2019 by the authors. Licensee MDPI, Basel, Switzerland. This article is an open access article distributed under the terms and conditions of the Creative Commons Attribution (CC BY) license (http://creativecommons.org/licenses/by/4.0/). 